\title{
Inventarisatie van arbeidsmarktonderzoeken onder afgestudeerden van het HBO
}

Citation for published version (APA):

van Dam, J. W., \& Mortier, M. (1990). Inventarisatie van arbeidsmarktonderzoeken onder afgestudeerden van het $H B O$. Researchcentrum voor Onderwijs en Arbeidsmarkt, Faculteit der Economische Wetenschappen. ROA Working Papers No. 1 https://doi.org/10.26481/umarow.1990001

Document status and date:

Published: 01/01/1990

DOI:

10.26481/umarow.1990001

Document Version:

Publisher's PDF, also known as Version of record

\section{Please check the document version of this publication:}

- A submitted manuscript is the version of the article upon submission and before peer-review. There can be important differences between the submitted version and the official published version of record.

People interested in the research are advised to contact the author for the final version of the publication, or visit the DOI to the publisher's website.

- The final author version and the galley proof are versions of the publication after peer review.

- The final published version features the final layout of the paper including the volume, issue and page numbers.

Link to publication

\footnotetext{
General rights rights.

- You may freely distribute the URL identifying the publication in the public portal. please follow below link for the End User Agreement:

www.umlib.nl/taverne-license

Take down policy

If you believe that this document breaches copyright please contact us at:

repository@maastrichtuniversity.nl

providing details and we will investigate your claim.
}

Copyright and moral rights for the publications made accessible in the public portal are retained by the authors and/or other copyright owners and it is a condition of accessing publications that users recognise and abide by the legal requirements associated with these

- Users may download and print one copy of any publication from the public portal for the purpose of private study or research.

- You may not further distribute the material or use it for any profit-making activity or commercial gain

If the publication is distributed under the terms of Article $25 \mathrm{fa}$ of the Dutch Copyright Act, indicated by the "Taverne" license above, 


\section{INVENTARISATIE VAN ARBEIDSMARKTONDERZOEKEN \\ ONDER AFGESTUDEERDEN VAN HET HBO \\ J.W. van Dam en M. Mortier}

ROA-W-1990/1

RESEARCHCENTRUM VOOR ONDERWIJS EN ARBEIDSMARKT

Faculteit der Economische Wetenschappen

Rijksuniversiteit Limburg

Maastricht, maart 1990 
CIP-GEGEVENS KONINKLIJKE BIBLIOTHEEK, DEN HAAG

Dam, J.W. van

Inventarisatie van arbeidsmarktonderzoeken onder afgestudeerden van het HBO/J.W. van Dam, M. Mortier. - Maastricht: Researchcentrum voor Onderwijs en Arbeidsmarkt, Faculteit der Economische Wetenschappen, Rijksuniversiteit Limburg. - (Rapport / Researchcentrum voor Onderwijs en Arbeidsmarkt; 1990/1)

Met lit. opg.

ISBN 90-5321-029-6 in spiraalband

SISO 318.7 UDC $331.5+377.5(492)$

Trefw.: hoger beroepsonderwijs en arbeidsmarkt; Nederland; onderzoek. 
1. INLEIDING 1

1.1. Doelstelling van de inventarisatie 1

1.2. Werkwijze bij deze inventarisatie 2

1.3. Indeling van het rapport 3

2. HET ROA-INFORMATIESYSTEEM ONDERWIJSARBEIDSMARKT 4

2.1. Inleiding 4

2.2. Uitgangspunten voor het informatiesysteem 4

2.3. De benodigde gegevens en de geïnventariseerde onderzoeken 5

2.4. Criteria waaraan de onderzoeken moeten voldoen 7

3. ARBEIDSMARKTONDERZOEKEN EN GEGEVENSBESTANDEN BIJ HOGESCHOLEN 9

3.1. Onderzoeken en gegevensbestanden 9

3.2. De mate waarin gegevens worden bijgehouden 11

3.3. Onderzoek en voorlichting 12

3.4. Verenigingen van afgestudeerden 13

3.5. Arbeidsmarktonderzoeken door hogescholen 14

3.6. Conclusies 17

4. ONDERZOEKEN DOOR EEN AANTAL KOEPELORGANISATIES 20

4.1. De geselecteerde onderzoeken 20

4.2. De onderzoeken beschreven en getoetst 21

4.3. De criteria nogmaals bekeken 33

4.4. Conclusies 34

5. CONCLUSIES EN AANBEVELINGEN 36

$\begin{array}{ll}\text { LITERATUUR } & 40\end{array}$

BIJLAGE I : Vragenlijst voor HBO-faculteiten

BIJLAGE II : Onderzoeken naar de arbeidsmarktpositie en het loopbaanverloop van afgestudeerden van hogescholen

BIJLAGE III: De mate waarin door faculteiten gegevens over afgestudeerden worden bijgehouden, naar HBO-sector

BIJLAGE IV : Voorlichting en onderzoek per HBO-sector: verleden en voornemens

BIJLAGE V : Rubs-vragenlijst 
Dit werkdocument bevat een inventarisatie van de arbeidsmarktonderzoeken die in ons land door hogescholen en HBO-samenwerkingsverbanden zijn verricht onder afgestudeerde HBO-ers. Ter inleiding wordt een beeld geschetst van het informatiesysteem voor onderwijs en arbeidsmarkt dat door het Researchcentrum voor Onderwijs en Arbeidsmarkt wordt ontwikkeld. De inventarisatie is opgezet als een speurtocht naar informatiebronnen die in dit informatiesysteem zouden kunnen worden ingepast. Het rapport wordt afgesloten met een aantal aanbevelingen om een onderlinge vergelijking van de resultaten van dergelijke onderzoeken in de toekomst mogelijk te maken.

De belangrijkste conclusies van deze inventarisatie zijn:

- Bij 40\% van de 150 HBO-faculteiten die reageerden worden adressen bijgehouden van afgestudeerden. Vrijwel iedere HBO-faculteit vermeldt in haar werving en voorlichting het beoogde beroepenspectrum waarvoor zij opleidt;

- Bij 30\% van de HBO-faculteiten die reageerden is ooit onderzoek verricht naar de eerste bestemming van de afgestudeerden op de arbeidsmarkt. In een aantal HBO-sectoren (kunst, techniek, sociaal-agogisch werk) wil men het onderzoek naar de arbeidsmarktpositie van afgestudeerden uitbreiden;

- De resultaten van eerste-bestemmingsonderzoeken die zijn verricht door individuele HBO-faculteiten of -studierichtingen zijn noch onderling vergelijkbaar, noch vergelijkbaar met bijvoorbeeld CBS-gegevens. Dit wordt vooral veroorzaakt door grote verschillen in de vraagstelling en in de classificatie van de antwoorden. De arbeidsmarktonderzoeken van enkele beroepsverenigingen en samenwerkingsverbanden van HBO-opleidingen bieden in potentie meer mogelijkheden tot onderlinge vergelijking dan het onderzoek van afzonderlijke opleidingen;

- Het onderzoek naar de eerste bestemming van afgestudeerden van het HBO zou een aanzienlijke meerwaarde krijgen indien de verkregen resultaten onderling vergelijkbaar zouden zijn. Dit is niet alleen van belang voor de afzonderlijke hogescholen en hun relaties maar ook voor het HBO als geheel.

- De onderlinge vergelijkbaarheid van de resultaten van het onderzoek onder afgestudeerde HBO-ers is het meest gebaat met het bevorderen van de samenwerking en coördinatie bij dit onderzoek. Daarbij kan met name worden gedacht aan de ontwikkeling van een onderzoeksinfrastructuur en een (korte) standaardvragenlijst, die als basis voor eerste-bestemmingsonderzoek door alle hogescholen zou kunnen worden gebruikt. 
1. INLEIDING

1.1. Doelstelling van de inventarisatie

In 1986 is door het Ministerie van Onderwijs en Wetenschappen een meerjarige onderzoeksopdracht verstrekt aan het Researchcentrum voor Onderwijs en Arbeidsmarkt (ROA) voor het ontwikkelen van een informatiesysteem onderwijsarbeidsmarkt. Dit systeem zou de arbeidsmarktperspectieven van opleidingen en beroepen moeten weergeven. Deze gegevens zouden onder meer bruikbaar moeten zijn voor de studie- en beroepskeuzevoorlichting aan leerlingen en studenten in het voortgezet- en hoger onderwijs.

In het onderzoekprogramma van het ROA (Heijke, 1989) is de opzet van dit informatiesysteem verder uitgewerkt. De basis van het informatiesysteem bestaat uit de arbeidsmarktgegevens die afkomstig zijn van de Arbeidskrachtentellingen en de Enquête Beroepsbevolking (EBB) van het CBS. Deze databestanden bevatten echter geen gegevens op een voldoende laag aggregatieniveau, waardoor er slechts een beeld kan worden geschetst van de arbeidsmarktperspectieven van clusters van beroepen en studierichtingen. Om tot een verdere verbijzondering van de arbeidsmarktinformatie te komen is het in kaart brengen van de bestemming van afgestudeerden op de arbeidsmarkt en de beroepsperspectieven die zij daarbij hebben, van groot belang. Dit is ook de belangrijkste reden waarom het ROA betrokken is bij de pilotstudie 'Registratie Uitstroom en Bestemming van Schoolverlaters', het RUBS-project. Hierin wordt gezocht naar een onderzoeksopzet waarmee representatieve gegevens kunnen worden voortgebracht over schoolverlaters uit alle niveaus en richtingen van het reguliere voortgezette onderwijs ${ }^{1}$.

Eerder is door het ROA een werkdocument samengesteld over een inventarisatie van de onderzoeken die zijn verricht naar de arbeidsmarktpositie van afgestudeerden uit het Wetenschappelijk Onderwijs (Van Dam, De Grip, Heijke, 1988). De belangrijkste conclusie die op grond van deze studie kan worden getrokken, is dat er in Nederland nauwelijks databestanden ten aanzien van het Wetenschappelijk Onderwijs te vinden zijn (hetzij in de vorm van onderzoeksresultaten, hetzij in de vorm van leden-/adressenbestanden van verenigingen van afgestudeerden) die een adequate aanvulling kunnen vormen

1. Een evaluerend verslag van de pilot-studie binnen het RUBS-project zal in het voorjaar van 1990 verschijnen. 
op de beschikbare arbeidsmarktgegevens van het CBS. Hoewel er veel onderzoek wordt gedaan naar de arbeidsmarktpositie van pas-afgestudeerden, zijn de resultaten van deze onderzoeken zelden onderling vergelijkbaar. Dit wordt met name veroorzaakt doordat geen gebruik gemaakt wordt van een vergelijkbare vraagstelling met bijbehorende standaarddefinities en -classificaties. Bovendien hebben veel onderzoeken betrekking op een beperkte groep van afgestudeerden of zijn ze niet representatief voor een totale beroepsgroep omdat ze zich beperken tot de afgestudeerden van één faculteit van een universiteit.

Het doel van deze studie is een soortgelijke inventarisatie te verrichten van de onderzoeken die in ons land zijn verricht onder afgestudeerden uit het Hoger Beroeps Onderwijs.

\subsection{Werkwijze bij deze inventarisatie}

Om een zo volledig mogelijke inventarisatie te kunnen maken van de in ons land verrichte onderzoeken naar de arbeidsmarktbestemming van afgestudeerden uit het HBO, is gekozen voor een tweedeling van de informatieverzamelende instanties. In de eerste plaats betreft het de hogescholen. Deze zijn met medewerking van de HBO-Raad schriftelijk benaderd. De hierbij gehanteerde korte vragenlijst is als Bijlage I bij dit rapport opgenomen. Deze vragenlijst is door het ROA begin 1989 verzonden aan de voorzitters van de HBOhogescholen. Gedurende de eerste vier maanden van 1989 kwamen 150 vragenlijsten retour, veelal vergezeld van onderzoeksverslagen en dergelijke. Deze zijn zorgvuldig geïnentariseerd op basis van een aantal criteria. De resultaten hiervan zijn in hoofdstuk 3 opgenomen.

Het tweede gedeelte van deze inventarisatie betreft de onderzoeken die zijn verricht of geïnitieerd door overkoepelende organisaties als beroepsverenigingen en samenwerkingsorganen. Deze reiken verder dan de studentenpopulatie van één bepaalde hogeschool of faculteit. Ze zijn dan ook veelal systematischer van opzet ${ }^{2}$. Deze onderzoeken komen in hoofdstuk 4 ter sprake.

Bij deze inventarisatie is gebruik gemaakt van de HBO-sectorindeling van de HBO-Raad ${ }^{3}$. De criteria op basis warvan de verschillende onderzoeken

2. $\mathrm{Er}$ is geen systematisch onderzoek gedaan naar het bestaan van nieuwe rapporten waardoor volledigheid niet kan worden gegarandeerd.

3. Zie: HBO-Raad (1988). 
beoordeeld worden zijn dezelfde als die welke gehanteerd werden in het eerder genoemde werkdocument over de arbeidsmarkt- en loopbaanonderzoeken onder afgestudeerden uit het Wetenschappelijk Onderwijs. Deze zullen in paragraaf 2.4 worden toegelicht.

\subsection{Indeling van het rapport}

Alvorens in te gaan op de uitkomsten van deze inventarisatie wordt eerst in hoofdstuk 2 een schets gegeven van het informatiesysteem onderwijs-arbeidsmarkt dat door het ROA wordt ontwikkeld. Achtereenvolgens zullen daarin de uitgangspunten van het informatiesysteem (paragraaf 2.2), de daarvoor benodigde gegevens (paragraaf 2.3) en de bij de inventarisatie gehanteerde criteria (paragraaf 2.4) aan de orde komen.

De hoofdstukken 3 en 4 bevatten de belangrijkste uitkomsten van de uitgevoerde inventarisatie. Hierin worden alle bij ons bekende rapporten, notities en dergelijke, die betrekking hebben op de arbeidsmarktpositie van afgestudeerde HBO-ers, getoetst aan de in paragraaf 2.4 beschreven criteria. Eerst zal dit gebeuren voor de gegevensbronnen en onderzoeken die zijn verricht vanuit de opleidingen zelf (hoofdstuk 3). Daarna zal worden ingegaan op de onderzoeken die verricht zijn door overkoepelende organisaties (hoofdstuk 4).

De gebruiksmogelijkheden van de resultaten van (arbeidsmarkt-) onderzoeken onder schoolverlaters zouden sterk toenemen indien bij het opzetten en uitvoeren ervan een aantal praktische wenken in acht zou worden genomen. Deze komen in hoofdstuk 5 ter sprake. 


\section{HET ROA-INFORMATIESYSTEEM ONDERWIJS-ARBEIDSMARKT}

\subsection{Inleiding}

In dit hoofdstuk wordt dieper ingegaan op het beoogde informatiesysteem voor onderwijs en arbeidsmarkt. Eerst wordt stilgestaan bij de uitgangspunten voor dit systeem. Vervolgens zal worden aangegeven wat de benodigde gegevens voor dit informatiesysteem zijn, met als leidraad de standaardindelingen van het CBS. In de laatste paragraaf wordt op basis van deze uitgangspunten en standaardisaties een aantal criteria opgesteld waaraan het datamateriaal moet voldoen om een aanvuling te kunnen vormen op de beschikbare CBSgegevens.

\subsection{Uitgangspunten voor het informatiesysteem}

In het ROA-onderzoekprogramma 1988/1989 (Heijke, 1988) worden de volgende uitgangspunten genoemd voor het informatiesysteem onderwijsarbeidsmarkt:

1. Het systeem moet informatie opleveren welke bruikbaar is voor de studieen beroepskeuzevoorlichting ten behoeve van scholieren en studenten in respectievelijk het voortgezet en het hoger onderwijs.

2. De te verschaffen informatie moet van kwantitatieve aard zijn. Het gaat daarbij om het verschaffen van gegevens over de ontwikkeling van de werkgelegenheid in de verschillende sectoren van de arbeidsmarkt, de ontwikkeling van de onderscheiden categorieën van de beroepsbevolking (naar bijvoorbeeld beroep en opleiding), de doorstroming van leerlingen door de diverse delen van het onderwijs, en dergelijke.

3. Er moet optimaal profijt worden getrokken van reeds beschikbare kwantitatieve gegevens en bestaande kennis om de ontbrekende gegevens alsnog beschikbaar te maken.

4. Het informatiesysteem moet een duurzaam karakter hebben. Het gaat om een instrument dat de benodigde gegevens met regelmatige tussenpozen kan verschaffen, op basis van actuele inzichten.

Daar zou inmiddels als vijfde uitgangspunt aan kunnen worden toegevoegd dat het informatiesysteem een regionale component dient te bevatten. Dit is vooral ook voor het $\mathrm{HBO}$ van belang, nu uit recent onderzoek is gebleken dat ruim $70 \%$ van de HBO-studenten uit de direkte omgeving van de HBO-hogeschool afkomstig is. Ook blijken de afgestudeerden van het HBO nog steeds in 
overgrote meerderheid een baan te zoeken op de regionale arbeidsmarkt. (NIPO, 1990).

De in dit rapport besproken inventarisatie van arbeidsmarktonderzoeken onder afgestudeerden uit het HBO vindt plaats in het kader van het derde uitgangspunt. Daarnaast wordt getracht een zo volledig mogelijk overzicht te geven van de stand van zaken op dit onderzoeksterrein. Een dergelijk overzicht kan met name van belang zijn voor personen en instanties die een initiërende of uitvoerende rol spelen bij arbeidsmarkt- en loopbaanonderzoek onder HBOers.

\subsection{De benodigde gegevens en de geïnventariseerde onderzoeken}

Met het informatiesysteem voor onderwijs en arbeidsmarkt worden twee doelen beoogd: ten eerste het 'monitoren' van kortetermijn ontwikkelingen op de arbeidsmarkt. Verdringingsprocessen tussen verschillende categorieën opgeleiden en de arbeidsmarktflexibiliteit van de afgestudeerden van een bepaalde opleiding zouden in dat verband kunnen worden waargenomen (De Grip en Heijke, 1989). Ten tweede zouden prognoses van de uitstroom uit het onderwijs moeten worden opgesteld. Door een confrontatie van vraag en aanbod zouden dan prognoses van arbeidsmarktontwikkelingen op de middellangetermijn berekend kunnen worden.

Het binnen het ROA ontwikkelde prognosemodel is opgebouwd uit drie stappen (De Grip e.a., 1987). Eerst wordt een raming gemaakt van de werkgelegenheid in de verschillende bedrijfssectoren. Vervolgens dienen deze prognoses als basis voor de werkgelegenheidsprognoses naar beroepsklassen. De laatste stap is het omzetten van deze prognoses per beroepsklasse in prognoses van de werkgelegenheid naar opleidingstypen en studierichtingen.

Voor deze monitoring en arbeidsmarktprognoses zijn in ieder geval de volgende gegevens over afgestudeerden nodig:

- In welke opleiding en richting men is afgestudeerd;

- De huidige positie op de arbeidsmarkt (werkend, arbeidsongeschikt, werkzoekend, vervolgopleiding volgend, etcetera);

- In welke beroepen de afgestudeerden werkzaam zijn (indien men werkzaam is);

- In welke bedrijfsklassen de afgestudeerden werkzaam zijn; 
- De geografische bestemming van de afgestudeerden.

Centraal in deze studie staat de vraag in hoeverre bestaande arbeidsmarktonderzoeken onder afgestudeerden informatie bevatten over de bovenstaande variabelen. Bovendien zijn alleen die onderzoeken van belang waarin alle vier variabelen zijn opgenomen. Deze beperking betekent in concreto dat het vooral de zogeheten 'first-destination surveys' en loopbaanonderzoeken zijn, die een inventarisatie rechtvaardigen.

Een belangrijke doelstelling van de inventarisatie is het, per HBO-sector, vaststellen van de mate warin informatie over de arbeidsmarktpositie enperspectieven van afgestudeerden beschikbaar is. Daarbij ligt de nadruk op informatie over de bovengenoemde vier variabelen. Daarnaast bieden eerstebestemmingsonderzoeken ('first-destination surveys') vaak de mogelijkheid om naast de benodigde gegevens over opleiding, arbeidsmarktsituatie, beroep en bedrijfsklasse per afgestudeerde, ook aanvullende gegevens te verzamelen die van belang zijn voor de aansluiting tussen het genoten onderwijs en het beroepsleven. Het betreft informatie over bijvoorbeeld:

- de voor de functie die men uitoefent benodigde vooropleiding;

- de (eventueel) benodigde werkervaring;

- de (eventueel) benodigde aanvullende cursussen;

- het (aanvangs)salaris.

Bij deze inventarisatie zijn de onderzoeken gerangschikt volgens de indeling in $\mathrm{HBO}$-onderwijssectoren 4 . In tabe 1 1. wordt deze indeling weergegeven.

Tabel 1. HBO-sector indeling

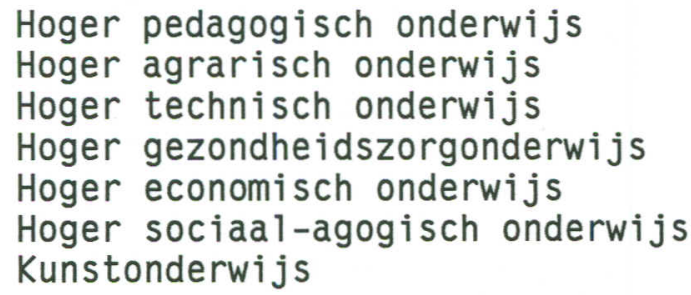

Deze indeling is minder specifiek dan de Standaard Onderwijs Indeling (SOI)

4. Bron: HBO-Raad (1988). 
van het CBS, maar wordt door veel hogescholen gebruikt bij de indeling van de opleiding in faculteiten of sectoren.

\subsection{Criteria waaraan de onderzoeken moeten voldoen}

De inventarisatie van de 'first-destination surveys' en loopbaanonderzoeken zal aan de hand van een aantal criteria worden verricht. Indien de resultaten van een onderzoek onder afgestudeerden aan deze criteria voldoen is een onderlinge vergelijking mogelijk en zouden zij opgenomen kunnen worden in het eerder genoemde informatiesysteem onderwijs-arbeidsmarkt. De eisen waaraan de onderzoeksresultaten moeten voldoen, zijn:

1) representativiteit;

2) consistentie;

3) koppelbaarheid;

4) actualiteit;

5) toegankelijkheid;

6) regelmatige herhaling.

De geïnventariseerde onderzoeken zijn allen getoetst aan de bovenstaande zes criteria. Daarvan wordt in de hoofdstukken 3 en 4 verslag gedaan. De zes criteria worden hieronder toegelicht.

ad 1) De onderzoekspopulatie moet representatief zijn voor de populatie waarover men een uitspraak wil doen. Representativiteit kan worden achterhaald door een bepaalde verdeling van een kenmerk over de onderzoekspopulatie (bijvoorbeeld geslacht) te vergelijken met de verdeling van dat kenmerk binnen de totale populatie. Bij representativiteit speelt omvang van de respons van de afgestudeerden een belangrijke rol. Bij een hoge respons zal de representativiteit doorgaans groter zijn. Bij first-destination onderzoek is vooral de vraag van belang of het percentage werkenden en hun spreiding over beroepen en bedrijfsklassen binnen de responsgroep representatief is voor de totale populatie afgestudeerden.

ad 2) Het onderzoek moet consistent zijn zodat een vergelijking met andere onderzoeken mogelijk is. Dit kan beoordeeld worden door te kijken of de gebruikte definities en onderzoekspopulaties overeenkomen met die van andere studies en de algemene 'standaard' definities. Naast externe consistentie moet er ook sprake zijn van interne consistentie: er mogen geen witte 
plekken of dubbeltellingen voorkomen.

ad 3) Het derde criterium wordt gevormd door de mate waarin de primaire gegevens van een onderzoek, in de vorm van een databestand, zijn te koppelen aan de gegevens van andere onderzoeken. Deze koppelbaarheid is sterk afhankelijk van de wijze waarop de primaire onderzoeksgegevens bewaard zijn gebleven en, indien ze geclassificeerd en gecodeerd zijn, de wijze waarop dat is gedaan. Geclassificeerde gegevens over variabelen zijn alleen te gebruiken indien deze gecodeerd zijn aan de hand van de internationaal gehanteerde classificaties voor opleiding, bedrijf en beroep, of indien zij daarop zijn terug te voeren. Dit zal dan ook een belangrijk criterium dienen te zijn bij de beoordeling van de arbeidsmarktonderzoeken.

ad 4) Om nog enigszins actueel te zijn moet de enquête ten hoogste vijf jaar geleden gehouden zijn. Oudere gegevens zijn in verband met de snelle ontwikkelingen op de arbeidsmarkt nauwelijks nog zelfstandig bruikbaar. Dit is vanzelfsprekend niet het geval bij periodieke metingen. De tijdreeksen die hieruit ontstaan kunnen nuttige informatie opleveren (zie ook ad 6).

ad 5) Ook de toegankelijkheid van de onderzoeksgegevens is van belang. Om de resultaten van het arbeidsmarktonderzoek, en met name het bijbehorende databestand, te kunnen gebruiken voor secundaire analyses moeten ze opgenomen zijn in een computerbestand en mogen er geen belemmeringen (bijvoorbeeld van juridische of organisatorische aard) zijn die het gebruik ervan in de weg staan.

ad 6) Er moet sprake zijn van regelmatige herhaling van de gegevensverzameling, om de ontwikkelingen in het desbetreffende arbeidsmarktsegment in kaart te kunnen brengen. Hierbij moeten de onderzoekspopulatie, de onderzoeksvragen en de onderzoekopzet over de gehele periode gelijk zijn gebleven.

Deze zes criteria worden gehanteerd bij de toetsing van zowel de eerste bestemmingsenquêtes en loopbaanonderzoeken van hogescholen als de onderzoeken die zijn verricht door overkoepelende organisaties zoals beroepsverenigingen en samenwerkingsorganen van scholen. Daarnaast worden bij de laatstgenoemde categorie onderzoeken nog een aantal aanvullende vragen gesteld. Deze komen in paragraaf 3.3. aan de orde. 


\section{ARBEIDSMARKTONDERZOEKEN EN GEGEVENSBESTANDEN BIJ HOGESCHOLEN}

\subsection{Onderzoeken en gegevensbestanden}

In januari 1989 is door het ROA een korte vragenlijst verzonden naar de centrale besturen van alle hogescholen die onder de HBO-wet vallen. Dat waren er op dat moment 94. Deze lijst ging vergezeld van een begeleidend schrijven van de HBO-Raad, gericht aan de Colleges van Bestuur van de hogescholen 5 . Ook zijn acht hogescholen uit de sector gezondheidszorg, die niet onder de HBO-wet vallen, aangeschreven ${ }^{6}$. In februari werden bij wijze van rappellering nogmaals vragenlijsten verstuurd naar hogescholen die nog niet gereageerd hadden.

Aan de hogescholen is verzocht om per faculteit of afdeling (afhankelijk van de naamgeving) een vragenlijst in te vullen. In de vragenlijst komen de volgende items aan de orde:

- in hoeverre houdt de hogeschool op facultair- of sectorniveau op systematische wijze gegevens bij omtrent afgestudeerden;

- om wat voor gegevens gaat het hier (adres, beroep, werkgever, en dergelijke);

- worden deze gegevens voor de gehele sector bijgehouden;

- worden deze gegevens in een geautomatiseerd databestand opgeslagen.

Dezelfde vragen werden gesteld over de gegevensbestanden van verenigingen van afgestudeerden. Vervolgens wordt gevraagd of er vanuit de sector bij de voorlichting aan aspirantstudenten melding wordt gemaakt van de arbeidsmarktperspectieven voor afgestudeerden van de betreffende opleiding. Tevens wordt gevraagd of er, al dan niet met behulp van de eerder genoemde adressenbestanden, onderzoek heeft plaatsgevonden of zal plaatsvinden naar de arbeidsmarktpositie en het loopbaanverloop van de afgestudeerden binnen de sector.

De respons op deze enquête bedroeg 75 procent. Dit komt neer op 150 reacties van de 201 te onderscheiden faculteiten (of sectoren) binnen de hogescholen.

5. Zie Bijlage I voor de volledige vragenlijst.

6. Het betreft hier de opleidingen oefentherapie Mensendieck, oefentherapie Cesar, drie opleidingen tot verloskundige en drie opleidingen tot mondhygiënist. 
In tabel 2. is de respons naar HBO-sector gespecificeerd. Hieruit blijkt dat met name de agrarische sectoren nauwelijks gereageerd hebben, terwijl de respons voor de andere sectoren tussen de 71 en 81 procent 1igt. De reden voor de geringe respons vanuit de agrarische sector is vermoedelijk gelegen in het feit dat de Stichting Samenwerking Hoger Agrarisch Onderwijs enquêtes verricht onder afgestudeerden uit deze sector, waardoor deze faculteiten zich wellicht niet geroepen voelden om te reageren ${ }^{7}$. Hoewel er van een bevredigende respons sprake is mag betwijfeld worden of de uitkomsten van de inventarisatie ook representatief zijn voor alle HBO-hogescholen. Een faculteit waraan een onderzoek onder afgestudeerden is verricht, zal immers eerder responderen dan een faculteit waar dat niet heeft plaatsgevonden.

Tabel 2. Respons van HBO-faculteiten per HBO-sector

\begin{tabular}{lccc}
\hline HBO-sector & $\begin{array}{c}(1) \\
\text { populatie }\end{array}$ & $\begin{array}{c}(2) \\
\text { respons } \\
(\text { abs. })\end{array}$ & $\begin{array}{c}(3) \\
\text { respons } \\
(\%)\end{array}$ \\
\hline - pedagogisch & 49 & 36 & 73 \\
2 - agrarisch & 8 & 2 & 25 \\
3 - technisch & 30 & 26 & 87 \\
4 - gezondheidszorg & 31 & 23 & 74 \\
5 - economisch & 37 & 30 & 70 \\
- sociaal-agogisch & 26 & 18 & 75 \\
7 - kunst & 20 & 15 & 75 \\
Totaal & 201 & 150 & \\
\hline
\end{tabular}

De indeling van de hogescholen in faculteiten is ontleend aan de HBO-Almanak 1988. Hierin worden de ongeveer 100 hogescholen niet alleen in sectoren maar ook in faculteiten onderscheiden. De niet altijd eenduidige naamgeving binnen de scholen bemoeilijkte een consistente indeling. De ene school spreekt van sectoren. Anderen spreken daarentegen van faculteiten, afdelingen, vakgroepen of instituten. In dit rapport wordt voortaan gesproken over faculteiten.

De resultaten van deze enquête worden in de volgende paragrafen besproken. Achtereenvolgens komen aan de orde:

1. De mate warin hogescholen en bijbehorende faculteiten gegevens over

7. Recentelijk verscheen De HAO-ingenieur in functie (1988). 
afgestudeerden verzamelen en bijhouden ná het voltooien van de opleiding (paragraaf 3.2.);

2. De vraag of hogescholen bij de voorlichting aan aspirant-studenten gebruik maken van arbeidsmarktgegevens. (paragraaf 3.3.);

3. De mate waarin verenigingen van afgestudeerden verbonden zijn aan de faculteiten. (paragraaf 3.4.);

4. De mate warin (arbeidsmarkt)analyses worden verricht met de aanwezige data (paragraaf 3.5.);

In de laatste paragraaf wordt een aantal conclusies geformuleerd met betrekking tot het onderzoek onder afgestudeerden door faculteiten en hogescholen.

\subsection{De mate waarin gegevens over afgestudeerden worden bijgehouden}

In de enquête is aan de faculteiten gevraagd om aan te geven in hoeverre er gegevens over afgestudeerden worden bijgehouden. In figuur 3.1 wordt voor de 7 HBO-sectoren grafisch weergegeven in welke mate dit, bij de faculteiten die reageerden, op systematische wijze wordt gedaan. Dit blijkt redelijk gunstig te zijn: bij $40 \%$ van de faculteiten die reageerden (59 van de 150) wordt op een min of meer systematische wijze gegevens bijhouden over hun afgestudeerden. Bij 32 van deze 59 faculteiten (21\% van het totaal) bestaan deze gegevens uit zowel naam en adres van de afgestudeerden als het beroep, de werkgever en eventuele andere gegevens zoals de gepercipieerde aansluiting tussen de gevolgde opleiding en het huidige beroep. In de overige 27 gevallen werden niet alle drie eerder genoemde kenmerken bijgehouden.

Van de 59 faculteiten die gegevens bijhouden zijn er 23 die dat op een geautomatiseerde wijze doen. Door 10 van de 59 faculteiten worden alleen op beperkte schaal gegevens bijgehouden over een deel van de afgestudeerden. Bijvoorbeeld alleen voor een bepalde studierichting.

Als de resultaten worden uitgesplitst naar $\mathrm{HBO}$-sector, zoals weergegeven in figuur I, dan blijkt dat vooral binnen de sectoren van het economisch-, het sociaal-agogisch- en het kunstonderwijs ongeveer de helft van de faculteiten die gereageerd hebben, gegevens bijhouden over hun afgestudeerden. In de overige HBO-sectoren ligt dit aandee 1 tussen 20 en 30 procent. Van de drie met name genoemde HBO-sectoren wordt binnen de sector economie ook hoog gescoord op de drie bovengenoemde subvragen, hetgeen wil zeggen dat de faculteiten in deze sector een compleet overzicht hebben over 
de gehele sector en dat deze gegevens op geautomatiseerde wijze worden bijgehouden. Voor de overige HBO-sectoren blijkt daarentegen dat er nog nauwelijks geautomatiseerde gegevensbestanden over afgestudeerden aanwezig zijn.

Figuur I De mate waarin door faculteiten op een min of meer systematische wijze gegevens worden bijgehouden over afgestudeerden, per HBOsector ${ }^{8}$.

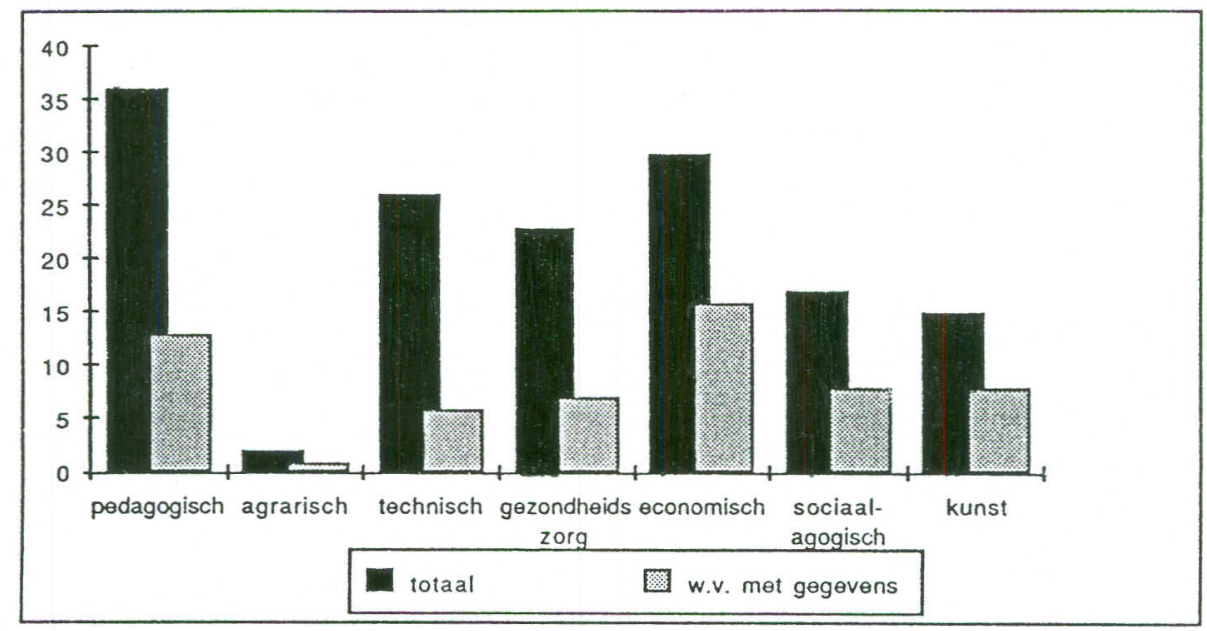

\subsection{Onderzoek en voorlichting}

In de enquête die naar de hogescholen is gestuurd is ook de vraag gesteld of in de voorlichting naar aankomende studenten melding wordt gemaakt van de beroepsmogelijkheden en arbeidsmarktperspectieven van de betreffende sector of opleiding. De resultaten op deze vraag zijn in figuur II weergegeven. De overgrote meerderheid (96 procent) van de faculteiten zegt dit te doen, alhoewel dit voor de opleidingen in de kunstsector iets minder vanzelfsprekend is. Uit deze figuur wordt tevens duidelijk dat er in het verleden weinig onderzoek plaats heeft gevonden onder afgestudeerden. Eveneens is goed zichtbaar dat een aantal faculteiten hieraan meer aandacht wil gaan schenken, met name in de sector Techniek.

8. Voor een cijfermatig overzicht: zie tabel III, Bijlage III. 
Figuur II Voorlichting en onderzoek per HBO-sector: verleden en voornemens ${ }^{9}$.

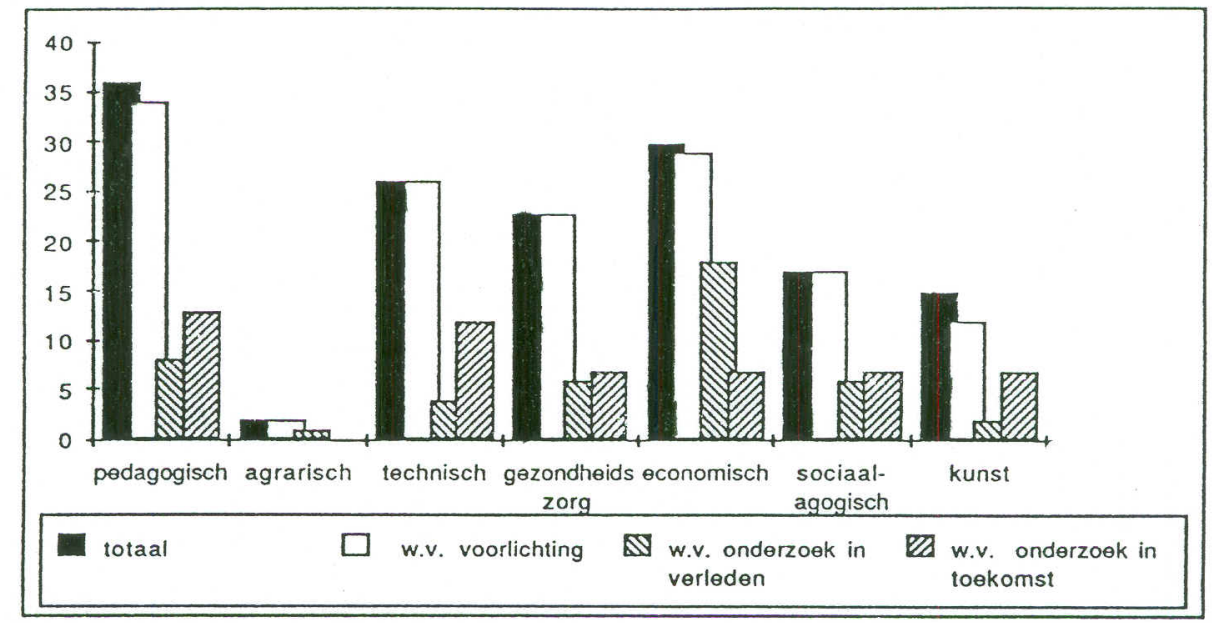

Het verschil tussen enerzijds de grote aandacht voor de beroepsmogelijkheden in de studievoorlichting en anderzijds de geringe (maar groeiende) hoeveelheid empirisch onderzoek hiernaar, is opmerkelijk. De vraag dringt zich op waarop de voorlichting over arbeidsmarktperspectieven is gebaseerd nu het onderzoek hiernaar nog gering is. Wellicht wordt in de voorlichting vooral gewezen op de beóógde beroepen en werkvelden.

Als we naar de gegevens per HBO-sector kijken, dan blijkt dat de economische faculteiten hierin, evenals in het bijhouden van adressen van afgestudeerden, het meest actief zijn. Dit is niet verwonderlijk aangezien een actueel en volledig adressenbestand een noodzakelijke voorwaarde vomt voor het verrichten van eerste-bestemmings- en loopbaanonderzoek. Ongeveer 60 procent van de economische faculteiten die reageerden volgt haar afgestudeerden. Voor de andere HBO-sectoren varieert dit percentage tussen de 13 en de 35 procent.

\subsection{Verenigingen van afgestudeerden}

Omdat het vermoeden bestond dat een faculteit met een vereniging van afgestudeerden meer mogelijkheden heeft om onderzoek te doen onder oud-

9. Een cijfermatig overzicht staat in tabel IV, in bijlage IV. 
studenten, is een vraag hieromtrent opgenomen in de vragenlijst. Daaraan was tevens de vraag verbonden of deze vereniging een ledenbestand heeft met daarin gegevens over beroep en werkgever van de leden-afgestudeerden. Uit de reacties is gebleken dat 26 van de 150 faculteiten die reageerden, een vereniging van afgestudeerden hebben. In tabel 3. zijn de reacties samengevat. Hieruit blijkt dat het met name de economische faculteiten zijn die een dergelijke vereniging hebben. Daarvan heeft minder dan de helft een bestand met daarin ook gegevens over functie en werkgever van de ledenafgestudeerden.

Tabe1 3. De verenigingen van afgestudeerden van HBO-faculteiten en de aanwezigheid van een bruikbaar adressenbestand, per sector

HBO-sector aantal verenigingen warvan met bruikbaar bestand

1 - pedagogisch

2 - agrarisch

3 - technisch

4 - gezondheidszorg*

5 - economisch**

6 - sociaal-agogisch

7 - kunst

Totaal

$\begin{array}{rr}0 & 0 \\ 1 & 0 \\ 4 & 2 \\ 3 & 3 \\ 22 & 9 \\ 0 & 0 \\ 0 & 0\end{array}$

30
2
3
9
0

14

* Dit zijn de drie 'school-gebonden' beroepsverenigingen van de Mensen-
dieck-en de Cesar-opleiding en de opleiding tot mondhygiënist.
** Van deze 22 verenigingen behoren er vijf tot de HEAO Arnhem.

\subsection{Arbeidsmarktonderzoeken door hogescholen}

Aan de 30 faculteiten die te kennen hebben gegeven onderzoek onder afgestudeerden te verrichten, is gevraagd om hiervan een onderzoeksverslag mee te zenden. Deze 30 onderzoeken zijn in tabel 3.4 naar HBO-sector gespecificeerd. Door 18 van de 30 faculteiten is een onderzoeksverslag meegezonden. Een beknopt overzicht van deze 18 onderzoeken aan de hand van de in hoofdstuk 2 geformuleerde criteria is opgenomen in Bijlage II. 
Tabel 4. Onderzoeken door faculteiten per HBO-sector

HBO-sector aantal faculteiten aantal reakties aantal onderzoeken

1 - pedagogisch

2 - agrarisch

3 - technisch

4 - gezondheidszorg

5 - economisch

6 - sociaal-agogisch

7 - kunst

Totaal

49
8
30
31
37
25
20

201

36
2
26
23
30
17
15

150

\section{6}

1

3

3

13

2

2

30

Uit tabel 4. blijkt nogmaals dat de economische sectoren het meest actief zijn in het volgen van de afgestudeerden. Van de 30 faculteiten in de sector economie (hiertoe behoren naast de HEAO's ook onder andere: de Hotelschool, de Hogeschool voor Tourisme en Verkeer, Academies voor Documentatie en Informatie, etcetera) die reageerden hebben er 13 zelfstandig onderzoek verricht naar de arbeidsmarktpositie van hun afgestudeerden. Het betreft dus geen onderzoeken die samen met bijvoorbeeld de Nederlandse Ingenieursvereniging NIRIA zijn verricht.

De kwaliteit van de geïnventariseerde onderzoeken verschilt onderling zeer sterk. Het ene onderzoeksverslag bestaat uit niet meer dan een overzicht van enkele pagina's over beroepen en werkadressen van afgestudeerden die werkzaam zijn in het directe beroepsveld. Aan de andere kant zijn er ook zeer omvangrijke enquêtes met zeer gedetailleerde uitwerkingen. Non-respons analyses en significantietoetsen treft men echter niet aan. Deze grote verscheidenheid hangt samen met de uiteenlopende doelstellingen van de verschillende onderzoeken. Om een aantal te noemen: curriculumevaluatie, kwaliteitsbewaking, 'een beeld krijgen van de werksituatie', 'in kaart brengen van de aansluiting van het onderwijs op de arbeidsmarkt', 'een volledig beeld krijgen van het loopbaanverloop van afgestudeerden', 'welk percentage van de afgestudeerden heeft vast werk gevonden', 'aanvulling op de overheidsstatistieken nu deze achterhaald lijken te zijn', 'in kaart brengen van het beroepsbeeld van de afgestudeerden elektrotechniek', etcetera.

Alle aangetroffen onderzoeken hebben met elkaar gemeen dat als onderzoekmethode gebruik wordt gemaakt van een schriftelijke enquête onder oud- 
studenten, in enkele gevallen voorafgegaan of aangevuld met een telefonische recherche om adressen te achterhalen of bij wijze van rappellering.

De verschillen in omvang en kwaliteit van de gehanteerde vragenlijsten zijn enorm. Een eerste verschil betreft de anonimiteit. Zo werden bij vijf van de negen onderzoeken, waarbij een vragenlijst in de rapportage was opgenomen, aan de geënquêteerden gevraagd om het woonadres te verstrekken of te corrigeren in het geval dit gewijzigd was. Bij de vier andere onderzoeken (overigens wél de meest omvangrijke) bevatte de vragenijjst geen tot personen herleidbare gegevens of kenmerken. Een tweede verschil heeft betrekking op de omvang van de vragenlijsten. Enkele vragenlijsten bestaan uit drie of vier vragen, terwijl er ook een zeer omvangrijke vragenlijst van 50 vragen naar ons werd toegezonden. In àlle vragenlijsten wordt gevraagd naar de belangrijkste bezigheid nà het verlaten van de opleiding. Wel zijn er grote verschillen in de nauwkeurigheid van de vraagstelling en de detaillering van de antwoordmogelijkheden (indien er sprake is van een gesloten vraag). Een belangrijk nadeel van alle geïnventariseerde vragenlijsten is dat ze op dit punt niet aansluiten op de standaarddefinities van werkgelegenheid en werkloosheid. Hierdoor zijn de resultaten van deze onderzoeken niet te vergelijken met bijvoorbeeld de CBS-statistieken.

Een vraag die steeds gesteld wordt aan diegenen die werkzaam zijn, betreft de aard van de werkzaamheden. In 3 van de 9 vragenlijsten wordt dit gedaan middels een open vraag: 'wat is uw huidige beroep?' of middels een vraag om een overzicht te geven van de belangrijkste werkzaamheden na het verlaten van de opleiding. Alléén in deze gevallen is een vergelijking met nationale statistieken in principe mogelijk omdat de onderzoeksresultaten zijn te (her) coderen met behulp van de Beroepenclassificatie van het CBS.

In drie vragenlijsten is alleen een vraag opgenomen om te achterhalen ò men werkzaam is in het beroepensegment waarop de opleiding zich richt: 'bent u werkzaam in de milieusector?', of 'bent $u$ werkzaam als oefentherapeut Cesar?'. De overige drie vragenlijsten bevatten vragen naar het werkterrein en het soort beroep met gesloten antwoordmogelijkheden. Dit varieert van drie alternatieven (overheid, semi-overheid, bedrijfsleven) tot een reeks van 17 categorieën welke onder meer is samengesteld met behulp van de bedrijvenindeling van het weekblad Intermediair. Hoewel de laatstgenoemde indeling een doordachte indruk makt, heeft ook deze als bezwaar dat ze niet is ingedeeld op basis van de Standaard Bedrijfs Indeling (SBI) van het CBS 
waardoor een vergelijking met statistieken van het CBS niet mogelijk is. Bovendien is de indeling van Intermediair in 17 categorieën niet verfijnd genoeg. Ook is er in een aantal gevallen sprake van overlappende antwoordcategorieën.

In de 9 vragenlijsten komen naast de bovengenoemde vragen onderwerpen aan de orde als het salarisniveau, de wijze waarop men aan deze baan is gekomen, het opleidingsniveau van de persoon die voór de respondent de functie vervulde, de inhoud van de werkzaamheden, de samenstelling van het vakkenpakket en de mate waarin deze vakken aansluiten op de beroepssituatie. In een enkel geval komen ook de rechtspositie en diverse beroepsaspecten aan de orde.

Zeven van de negen onderzoeken zijn (gezien de toelichting bij de vragenlijst) eenmalig verricht. Bij twee van deze zeven onderzoeken bestaat overigens wel de mogelijkheid om het onderzoek te herhalen omdat ook gevraagd wordt om de correcte adresgegevens. Bij twee onderzoeken wordt expliciet melding gemaakt van het mogelijk wederkerend karakter, ofwel voor hetzelfde onderzoek onder een later cohort, ofwel voor een vervolgonderzoek bij hetzelfde cohort.

\subsection{Conclusies}

Uit een schriftelijke enquête die naar alle hogescholen in het Hoger Beroepsonderwijs is verstuurd, en waarop 150 faculteiten hebben gereageerd (75 procent), blijkt dat ongeveer 40 procent van de HBO-faculteiten die reageerden, gegevens verzamelen over afgestudeerden. De resultaten die dit oplevert zijn echter zelden vergelijkbaar met andere onderzoeken en databestanden doordat van eigen indelingen voor beroep en werkgever gebruik wordt gemaakt. Bovendien worden deze gegevens veelal op een weinig toegankelijke wijze bewaard, bijvoorbeeld alleen in de vorm van een stapel ingevulde vragenlijsten. Bij meer dan de helft van de faculteiten die gegevens over hun afgestudeerden bijhouden, gebeurt dit op een niet-geautomatiseerde wijze.

Opmerkelijk is dat de faculteiten uit de sector economie, waartoe overigens niet alleen de zuiver economische faculteiten behoren maar ook bijvoorbeeld de Academie voor Verkeer en Tourisme, de Academies voor Bibliotheek en Documentatie en de Hotelschool, hierop een positieve uitzondering vormen. Zij 
zijn ten opzichte van andere sectoren zeer actief in het verzamelen van gegevens en het onderzoeken van de loopbaanontwikkelingen van afgestudeerden. Toch moet ook bij deze onderzoeken een kanttekening worden geplaatst, want ook hiervan zijn de resultaten moeilijk te vergelijken met de onderzoeksresultaten van andere sectoren. Dit komt doordat bijna iedere faculteit bij haar arbeidsmarktonderzoek gebruik makt van zelf ontwikkelde vragenlijsten met een eigen specifieke vraagstelling waardoor vergelijking met andere onderzoeken niet mogelijk is. Dit is met name het geval bij vragen die zijn bedoeld om de huidige positie op de arbeidsmarkt vast te kunnen stellen. Deze vragen wijken tevens bijna altijd af van de standaarddefinities van werkgelegenheid (potentiële beroepsbevolking) en werkloosheid, die door het CBS worden gehanteerd.

Toch is er een voorzichtige vorm van samenwerking binnen een aantal sectoren te bespeuren ten aanzien van onderzoek onder afgestudeerden. We constateerden dat bij een aantal HEAO-opleidingen, bibliotheekacademies en HBO-J opleidingen gebruik is gemaakt van dezelfde of vergelijkbare vragenlijsten. Niettemin voldoen ook deze vragenlijsten niet aan de standaarddefinities en -classificaties. Meer geïnstitutionaliseerde vormen van samenwerking zoals in de agrarische- en de technische sector worden in de volgende paragraaf besproken.

Het meerendeel van de aangetroffen onderzoeken is verricht ten behoeve van intern gebruik. Daarbij is de evaluatie van het onderwijsprogramma vaak de voornaamste doelstelling. In slechts enkele gevallen is het onderzoeken van de ontwikkeling van de loopbanen van afgestudeerden het primaire doel ten einde daar voorlichtingsmateriaal voor aankomende studenten op te baseren. Het zal weinig verwondering wekken dat onderzoek om deze reden vooral interessant is voor die sectoren waarvan de arbeidsmarktperspectieven goed zijn (bijvoorbeeld economie). In enkele andere gevallen blijkt dat er beroepsverenigingen zijn die dergelijk onderzoek al verrichten zodat het voor de individuele scholen niet zinvol is om dit nog eens over te doen. Dit is vooral bij de agrarische- en de technische sector het geval.

De initiatieven die vanuit de afgestudeerden zelf komen, bijvoorbeeld door het oprichten van een vereniging van afgestudeerden, lijken zich te concentreren binnen de sector economie. Binnen de andere sectoren wordt weinig of geen melding gemaakt van de aanwezigheid van verenigingen van afgestudeerden. Over de bruikbaarheid van de gegevensbestanden van deze 
verenigingen kan niets gezegd worden.

Tevens is uit het onderzoek gebleken dat vrijwel alle hogescholen en faculteiten in hun voorlichting aan potentiële studenten melding zeggen te maken van de arbeidsmarktperspectieven van de opleiding. Men baseert zich daarbij waarschijnlijk vooral op contacten met het werkveld en op statistieken en gegevens van overheid en onderzoekinstellingen, want slechts 30 procent van de faculteiten die reageerden heeft eigen onderzoek verricht naar de loopbanen en de arbeidsmarktposities van haar afgestudeerden. Kwantitatief onderbouwde prognoses zal men overigens in de voorlichting aan toekomstig studenten nog niet veel aantreffen. 


\section{ONDERZOEKEN DOOR EEN AANTAL KOEPELORGANISATIES}

\subsection{De geselecteerde onderzoeken}

Bij de eerder beschreven verzameling en inventarisatie van rapporten over de arbeidsmarktsituatie van HBO-afgestudeerden, is een onderscheid gemaakt in onderzoek onder de afgestudeerden van één enkele opleiding of faculteit en onderzoek onder de afgestudeerden van meerdere en vergelijkbare studierichtingen dat bijvoorbeeld door of in opdracht van een samenwerkingsverband van hogescholen is verricht. Deze onderzoeken bestrijken doorgaans een grotere onderzoekspopulatie en wekken over het algemeen de indruk qua onderzoeksmethodiek en -instrumentarium beter ontwikkeld te zijn. De volgende negen onderzoeken zijn daarop geselecteerd voor nadere analyse:

1. Het bedrijfsleven als alternatief... voor leraren wiskunde/ natuurkunde/ scheikunde, landelijke hoofddocentenberaden wiskunde, natuurkunde, scheikunde, Tilburg, 1987.

2. Opleiding en arbeidsmarkt - Een onderzoek onder afgestudeerde biologieleraren aan NLO's, M. Tichelaar, Nederlands Instituut van Biologen (NIBI), Arbeidsmarktonderzoek 4, Utrecht, 1987.

3. Enquête schoolverlaters '86 '87 - Verslag van het dertiende onderzoek onder afgestudeerden van het harde HBO, Nederlandse Ingenieursvereniging NIRIA en de Nederlandse vereniging van Afgestudeerden aan Hogere Economische Scholen NAHES, Amerongen, 1987.

4. Een brede arbeidsmarkt - Rapport van een loopbaanonderzoek onder afgestudeerden van het hoger agrarisch onderwijs, Stichting Maatschappelijke Plaats Agrarische Ingenieurs MPAI, Wageningen, 1983.

5. De HAO-ingenieur in functie, Stichting Samenwerking Hoger Agrarisch Onderwijs (SHAO), Wageningen, 1988.

6. Eindverslag enquête onder jeugdwelzijnswerk(st)ers 85-86, Vereniging HBO-J, J. de Haan, Groningen 1987.

7. Opleiding en beroep geconfronteerd - Onderzoek naar de aansluitingsproblematiek bij Mikojel, R. van der Velden e.a., RION, Groningen, 1987.

8. Horeca-opgeleiden op de arbeidsmarkt, SVH-Onderwijscentrum van de bedrijfstak HORECA, Den Haag, 1985.

9. De samenhang onderwijs-beroepspraktijk in de sector van de beeldende kunsten, SCO, Amsterdam, 1987. 
Van deze onderzoeken zijn er drie die samen enkele sectoren in het geheel omvatten. Het gaat om de onderzoeken van het NIRIA, de MPAI en de stichting SHAO die globaal genomen betrekking hebben op het 'harde' HBO: het agrarisch, technisch en economisch onderwijs. Het NIRIA-onderzoek bevat tevens een deel van het laboratorium onderwijs en een deel van het nautisch onderwijs. Van de overige onderzoeken is de onderzoekspopulatie beperkt tot één bepaalde richting. Zo heeft het NIBI-onderzoek alleen betrekking op biologieleraren.

\subsection{De onderzoeken beschreven en getoetst}

Deze paragraaf bevat een korte beschrijving van de negen onderzoeken naar de arbeidsmarktpositie van HBO-afgestudeerden, afkomstig van een cluster van opleidingen of van een beroepsvereniging. Om deze inventarisatie overzichtelijk te laten verlopen is een aantal vragen opgesteld aan de hand waarvan de onderzoeken besproken zullen worden. Aan het einde van de beschrijving van een onderzoek is een overzicht opgenomen van de mate waarin voldaan is aan de zes in hoofdstuk 2 opgestelde criteria. Geconcludeerd kan worden dat er twee onderzoeken zijn waarmee een nadere kennismaking interessant kan zijn. Het gaat om de jaarlijkse NIRIA-enquête en het onderzoek onder afgestudeerden uit het hoger agrarisch onderwijs. Dit hoofdstuk wordt besloten met een korte bespreking van de uitkomsten per criterium.

De beschrijving vond plaats aan de hand van de volgende vragen:

A) Door wie en wanneer is het onderzoek uitgevoerd en wordt het regelmatig verricht?;

B) Om welke onderzoekspopulatie gaat het, onder welke HBO-sector valt deze populatie en hoe werd er met deze populatie contact gelegd?

C) Wat is de doelstelling van het onderzoek?

D) Welke onderzoekmethode is er gehanteerd?

E) Wat waren de belangrijkste vragen of items van het onderzoek?

F) Wat is de respons en in hoeverre is het onderzoek representatief?

G) Welke definities en classificaties zijn er gehanteerd en is het mogelijk om deze te vertalen naar CBS-classificaties?

H) Wat kan er geconcludeerd worden met betrekking tot de zes criteria (representativiteit, consistentie, koppelbaarheid, actualiteit, toegankelijkheid en herhaling)? De betekenis van de in de overzichten gehanteerde tekens is als volgt: ? = onbekend, - = slecht, + = goed, ++ = zeer goed, $+/-$ = twijfelachtig. 
De negen onderzoeken worden hieronder achtereenvolgens beschreven. Voor ieder onderzoek staat aangegeven op welke HBO-sector het onderzoek betrekking heeft.

\section{Pedagogisch onderwijs}

1. Het bedrijfsleven als alternatief... voor leraren wiskundel natuurkundel scheikunde. Landelijke hoofddocentenberaden wiskunde, natuurkunde, scheikunde, Tilburg, aug. 1987.

A. Dit eenmalige onderzoek is uitgevoerd door drs. F. Dekkers, drs. L. Kuijk en Dr. J. Slavenburg van het voormalig Moller-instituut (nu Hogeschool voor Katholieke Leergangen) te Tilburg in oktober 1987.

B. Onderzoekspopulatie: alle afgestudeerden én studenten vanaf 1982 van instituten voor tweede graads lerarenopleiding wiskunde, natuurkunde en/of scheikunde. Het contact met studenten en afgestudeerden werd door de hogescholen gelegd.

C. Doelstelling: op korte termijn een globale indicatie geven voor het percentage van de afgestudeerden die een werkkring buiten het onderwijsveld zoeken/vonden.

D. De onderzoekmethode: een kleine schriftelijke enquête die via de hogescholen onder de studenten en afgestudeerden werd gehouden. De enquêtes onder afgestudeerden en studenten bestonden uit één vraag. De verwerking vond op handmatige wijze plaats, de gegevens zijn niet geautomatiseerd.

E. De enige vraag die gesteld werd had betrekking op de werkplaats (binnen of buiten onderwijs of werk zoekend) van afgestudeerden en hun functie in het betreffende bedrijf (open vraag).

F. Het aantal respondenten was 595. Door de onderzoekers is geen nonresponsonderzoek verricht. Zij verwachten zelf dat de non-respons waarschijnlijk niet hoog zal zijn.

G. Gebruikte indelingen: voor opleiding: 3 classificaties (natuurkunde, scheikunde, wiskunde), voor beroep/functie: open vraag; voor bedrijf: is 
men werkzaam in of buiten het onderwijs. (In deze laatste categorie werd tevens gevraagd naar de naam van de hogeschool/bedrijf).

H. representativiteit consistentie koppelbaarheid actualiteit toegankelijkheid herhaling

De resultaten van dit onderzoek zijn niet bruikbaar voor het informatiesysteem onderwijs arbeidsmarkt.

\section{Pedagogisch onderwijs}

2. Opleiding en arbeidsmarkt - Een onderzoek onder afgestudeerde biologieleraren aan NLO's, NIBI, Utrecht, 1987.

A. Dit onderzoek is uitgevoerd door het Nederlands Instituut van Biologen (NIBI) onder leiding van mevr. drs. M. Tichelaar. De peildatum van de enquête was 1 maart 1983. De enquête ging uit in mei 1983. Het onderzoek is gepubliceerd in juli 1987. Dit is geen periodiek onderzoek.

B. Onderzoekspopulatie: alle, tussen sept. 1977 en juli 1983, afgestudeerden met een tweede- of derdegraads bevoegdheid biologie aan één van de 7 NLO's (Nieuwe Leraren Opleiding). De adressen werden geleverd door de hogescholen. Eventueel werd gebruik gemaakt van het ouder-lijk adres.

C. Doelstelling: "een zo volledig mogelijk arbeidsmarktbeeld van de ondervraagden" te krijgen aan de hand van informatie over hun opleiding, het werk (al dan niet betaald) en hun mening over de werkloosheid onder biologen.

D. Onderzoekmethode: een schriftelijke enquête die 80 vragen bevatte. De enquêtes zijn verwerkt met SPSS.

E. Belangrijkste onderzoeksvragen m.b.t.: 1) opleiding (plaats, jaar, inhoud opl., ervaring); 2) sollicitatie / beroepskeuze / loopbaan; 3) arbeidsplaats/arbeidsduur/werkloosheid.

F. Respons: $1113 / 498 * 100 \%=44.7 \%$ Representativiteit: geen relevant n.r.onderzoek verricht. 
G. Gebruikte indelingen:

6 bedrijfssectoren (onderzoek, onderwijs, beleid, bedrijfsleven, zelfstandig, anders)

60 beroepsgebieden (59 binnen biologie)

1 opleiding (NLO) naar 61 vakgebieden.

Deze classificaties sluiten niet aan op de standaard CBS-indelingen.

H. representativiteit consistentie koppelbaarheid actualiteit toegankelijkheid herhaling

De resultaten van dit onderzoek zijn niet bruikbaar voor het informatiesysteem onderwijs -arbeidsmarkt.

\section{Agrarisch, technisch en economisch onderwijs}

3. Enquête schoolverlaters $86 / 87$ - Verslag van het dertiende onderzoek onder afgestudeerden van het harde HBO, NIRIA, Amerongen, 1987.

A. Het onderzoek is uitgevoerd door de Nederlandse Ingenieursvereniging NIRIA i.s.m. de Nederlandse Vereniging van Afgestudeerden aan Hogere Economische Scholen NAHES 0.1.v. Drs. J.J.G.J. van Helvert. Dit is een periodiek onderzoek, gehouden voor de dertiende keer, voor de zesde maal i.s.m. NAHES. De enquête is gehouden in dec. 1986.

B. Onderzoekspopulatie: de 4.855 afgestudeerden aan de hogere agrarische, hogere laborato-rium-, hogere nautische, hogere technische en hogere economische en administratieve scholen. De afgestudeerden zijn schriftelijk benaderd.

C. Doelstelling: onderzoek naar de positie op de arbeidsmarkt van de afgestudeerden uit de vijf richtingen van het 'marktgerichte' hoger beroepsonderwijs.

D. Onderzoekmethode: een optisch inleesbare vragenlijst met 27 open en meerkeuze vragen (enquête 1987) onder alle genoemde afgestudeerden.

E. Belangrijkste onderzoeksvragen: richting van afstuderen, arbeidsduur, sollicitatie, bedrijfsgrootte, branche, beroep, inkomen, provincie, 
aansluiting onderwijs-arbeidsmarkt, reden van studiekeuze.

F. Respons: $2933 / 4855 * 100 \%=60.4 \%$. Geen non-respons onderzoek verricht.

G. Gebruikte indelingen:

32 branches (bedrijfssectoren);

23 beroepsaspecten;

54 studierichtingen;

Studierichtingen zijn mogelijk te aggregeren en vervolgens aan te sluiten op CBS-classificaties. Voor de 32 branches moet een koppeling mogelijk zijn met de Standaard Bedrijfsindeling van het CBS. De "beroepsaspecten" sluiten echter niet aan op de CBS Beroepenclassificatie 1984.

H. Conclusie: Dit periodieke onderzoek onder de 'harde HBO-ers met een geautomatiseerd bestand kan bruikbaar zijn. Nadeel is echter het ontbreken van een goede beroepenclassificatie. Een voordeel is dat de NIRIA-enquête naar een grote groep afgestudeerden gaat.

representativiteit consistentie koppelbaarheid actualiteit toegankelijkheid herhaling

? + + + l- $\quad+\quad+\quad++$

De resultaten van de NIRIA-onderzoeken zijn om verschillende redenen zeer interessant voor het informatiesysteem onderwijs-arbeidsmarkt. Indien met het NIRIA overeenstemming bereikt zou kunnen worden over het gebruik van de ruwe dataset dan zou nader onderzoek verricht kunnen worden naar de representativiteit en de koppelbaarheid.

\section{Agrarisch onderwijs}

4. Een brede arbeidsmarkt - Rapport van een loopbaanonderzoek onder afgestudeerden van het hoger agrarisch onderwijs, MPAI, 1983, Wageningen.

A. Het loopbaanonderzoek is in 1982 uitgevoerd door Maatschappelijke Plaats Wageningse Ingenieur in opdracht van de Stichting Maatschappelijke Plaats Agrarische Ingenieurs. Het betrof een eenmalig onderzoek.

B. Onderzoekspopulatie: alle afgestudeerden (vanaf $1912 \mathrm{t} / \mathrm{m}$ 1981) van de 
Hogere Agrarische Scholen (ook H.S. voor levensmiddelentechnologie, H.S. voor tuin- en landschapsinrichting en stichting tot opleiding van laboratoriumpersoneel), behalve zij die op 1 mei 1982 arbeidsongeschikt of gepensioneerd waren.

De adressen werden geleverd door de scholen (vaak via ver. van afgestudeerden). Tevens werd er een oproep geplaatst in de Vacaturegids van het Landbouwkundig Tijdschrift. Aan non-respondenten werd een tweede formulier gestuurd.

C. Doelstelling: "Geven van een beeld van de functies waarin afgestudeerden terecht komen, in welke marktsectoren en met welke functie-aspecten."

D. Onderzoekmethode: Het onderzoek bestond uit een schriftelijke enquête op een optisch leesbaar formulier. Verwerking geschiedde met SPSS.

E. Belangrijkste onderzoeksvragen hebben betrekking op: opleiding, kenmerken van functies, aansluiting van onderwijs op functies, mobiliteit, functieloosheid, situatie werkzoekenden, positie vrouwelijk afgestudeerden, wensen t.a.v. de opleiding.

F. De respons bedroeg $10479 / 6131 * 100 \%=58,5 \%$ Representativiteit: de afgestudeerden van 1978 t/m 1982 zijn sterk oververtegenwoordigd. Ook per school werden grote verschillen in respons geconstateerd (tussen $40 \%$ en $70 \%)$.

G. Gebruikte indelingen:

33 studierichtingen (allen binnen genoemde SOI sectoren op 5 digit niveau). 62 Bedrijfssectoren in 10 groepen, eigen indeling. 15 Functiegroepen (beroepen), eigen indeling.

De beroepen en bedrijfssectoren zijn niet ingedeeld volgens de CBSclassificaties. Wellicht zijn de bedrijfssectoren te koppelen aan de SBI van het CBS.

H. De afgestudeerden uit dit MPAI-onderzoek vallen tegenwoordig onder de onderzoekspopulatie van het NIRIA en de stichting SHAO.

representativiteit consistentie koppelbaarheid actualiteit toegankelijkheid herhaling 
Het betreft een omvangrijk en diepgaand onderzoek. Verdere oriëntatie is echter niet nodig vanwege het eenmalige karakter.

\section{Agrarisch onderwijs}

5. De HAO-ingenieur in functie, stichting SHAO, Wageningen, 1988.

A. Het loopbaanonderzoek onder HAO (hoger agrarisch onderwijs)-ingenieurs is in 1987 uitgevoerd door mevr. ing. M. Gimbrère in opdracht van de stichting SHAO in navolging van het loopbaanonderzoek van de stichting MPAI. Waarschijnlijk wordt dit onderzoek herhaald.

B. Onderzoekspopulatie: alle afgestudeerden van agrarische hogescholen 1972 tot en met 1986, behalve afgestudeerden van het hoger agrarisch pedagogisch onderwijs. De afgestudeerden zijn schriftelijk benaderd.

C. Doelstelling: "Het verkrijgen van inzicht in de huidige positie van HAO ingenieurs in de beroepspraktijk en mogelijke ontwikkelingen daarvan in de toekomst."

D. Onderzoekmethode: Een schriftelijke enquête bestaande uit 61 vragen op optisch leesbare formulieren. Verwerking met SPSS.

E. Belangrijkste onderzoeksvragen hebben betrekking op de eerste functie (soort functie, invloed onderwijs), huidige functie (regio, salaris, dienstverband, soort functie, etc.), relatie met onderwijs, buitenlandervaring, nascholing en de ervaringen van vrouwen.

F. De respons van de bereikbare ingenieurs bedroeg $9064 / 5644 * 100 \%=$ $62 \%$. De representativiteit van de respondenten is "heel redelijk" voor de gehele populatie als er gekeken wordt naar school, studierichting, geslacht en afstudeerjaar.

G. Gebruikte indelingen:

9 studierichtingen (eigen indeling, wel koppelbaar met SOI)

76 bedrijfssectoren (uitgebreide sectorindeling van het CBS)

17 functiegroepen (eigen indeling) 
H. Dit onderzoek is voorlopig nog niet periodiek, maar is eventueel te koppelen aan de NIRIA en MPAI onderzoeken. Tevens kan verwacht worden dat dit onderzoek herhaald gaat worden.

representativiteit consistentie koppelbaarheid actualiteit toegankelijkheid herhaling

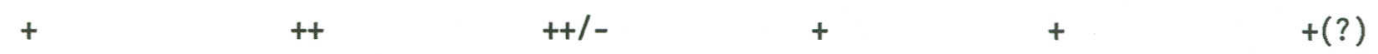

De resultaten van dit onderzoek zouden, indien het onderzoek regelmatig verricht wordt, een bijzonder nuttige aanvulling kunnen vormen op het informatiesysteem onderwijs-arbeidsmarkt.

\section{Sociaal-agogisch onderwijs}

6. Eindverslag enquête onder jeugdwelzijnswerk(st)ers 85-86, Jitze de Haan, Groningen, 1987.

A. Onderzoek uitgevoerd door J. de Haan e.a. onder verantwoordelijkheid van de 'Vereniging HBO-J'. Dit onderzoek is gehouden onder oud-studenten van het HBO-J in 1985 en 1986. Het is geen periodiek onderzoek. Er komt waarschijnlijk wel een vervolgonderzoek onder alle 9 HBO-J opleidingen in Nederland 0.1.v. dhr. Boonenkamp van de HBO-J "Jekerdal" in Maastricht i.s.m. Jitze de Haan (Universiteit Twente).

B. Onderzoekspopulatie zijn de HBO-J afgestudeerden van drie opleidingen voor de vermeldde jaren, in te delen in vier clusters ( 3 scholen):

Haren $\quad 78$ afgestudeerden (1983)

Maastricht A 71 afgestudeerden (1983/1984)

Maastricht B 95 afgestudeerden (1979/1982)

Rotterdam 56 afgestudeerden (1983)

De opleiding HBO-J valt onder SOI code 57118 (overig sociaal werk).

C. Doelstelling: "een beeld krijgen van de werksituatie van oud-studenten van de HBO-J en in kaart brengen hoe de aansluiting tussen opleiding en werk door hen werd ervaren."

D. Onderzoekmethode: een schriftelijke enquête onder de gehele onderzoeks populatie. Het bestand van de geretourneerde enquêtes is niet geautomatiseerd. 
E. Onderzoeksvragen hebben betrekking op: sollicitatie, beroep, soort werk, functie, aantal uren werkzaam, carrièreverloop, aansluiting van opleiding op werk.

F. Respons van $330 / 450 * 100 \%=67 \%$ Representativiteit: niet onderzocht.

G. Gebruikte indelingen: 12 werksoorten (bedrijf, m.n. specificaties van hulpverlenings-voorzieningen); 5 functies (beroep); De gebruikte classificaties sluiten niet aan op de CBS-classificaties.

H. Er zijn plannen voor herhaling van dit onderzoek waarbij echter een grotere populatie onderzocht zal worden. Het onderzoek en de bijbehorende data kunnen in de huidige vorm niet voor het informatiesysteem onderwijs - arbeidsmarkt gebruikt worden.

representativiteit consistentie koppelbaarheid actualiteit toegankelijkheid herhaling

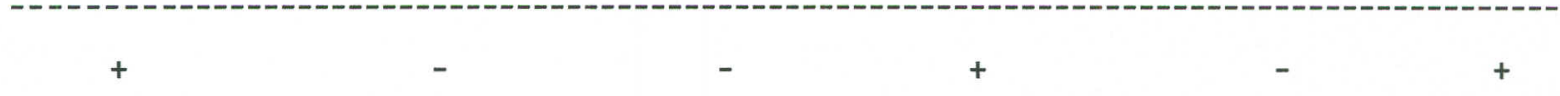

Oriëntatie op het voorgenomen vervolgonderzoek lijkt aan te bevelen.

\section{Sociaal-agogisch onderwijs:}

7. Opleiding en beroep geconfronteerd - Onderzoek naar de aansluitings problematiek bij Mikoje 1, RION, Groningen, 1987.

A. Onderzoek uitgevoerd door het RION in Groningen 0.1.v. R. van der Velden in opdracht van de Stichting voor Onderzoek van het Onderwijs (SVO). De dataverzameling vond plaats van dec. $1985 \mathrm{t} / \mathrm{m}$ maart 1986. Dit onderzoek is niet periodiek.

B. Onderzoekspopulatie: de afgestudeerden van de vier Mikojel opleidingen (Sittard, Middeloo, Jelburg en Kopse Hof) die in 1982 of 1983 de opleiding gediplomeerd verlieten. In total betreft het 500 afgestudeerden.

C. Doelstellingen:

- inzicht bieden in de beroepsloopbanen van de afgestudeerden van 
Mikojel opleidingen;

- in kaart brengen van de behoeften en verwachtingen die in het werkveld leven ten aanzien van de kwalificaties waarmee Mikojel afgestudeerden zijn uitgerust;

- aanwijzigingen op te leveren op welke wijze het opleidingsprogramma verbeterd kan worden.

Specifieke doelstelling m.b.t. de aanbod kant (afgestudeerden):

- wat zijn Mikojel afgestudeerden na de opleiding gaan doen;

- hoe is de arbeidsmarktpositie van de afgestudeerden;

- in welke functies komen ze terecht;

- hoe oordelen de afgestudeerden over de aansluiting tussen opleiding en beroepspraktijk.

D. Gevolgde onderzoekmethode:

1) schriftelijke enquête onder de afgestudeerden;

2) schriftelijke enquête onder werkgevers;

3) deskundigen onderzoek d.m.v. interviews.

E. Belangrijkste onderzoeksvragen (uit de enquête onder afgestudeerden) hadden betrekking op: functie, hogeschool, aanstelling, arbeidsduur, werkloosheid, sollicitatie, scholing.

F. Onderzoekspopulatie: van 550 uiteindelijk 378 opgenomen in bruikbaar bestand. Respons $378 / 550 * 100 \%=69 \%$. Representativiteit: niet nader onderzocht.

G. Gebruikte indelingen:

Eigen classificaties zowel voor bedrijfssector (24 hogescholen) als voor functie (open vraag). Deze classificaties sluiten niet aan op de CBS classificaties, maar zijn wellicht na (her)-coderen aan te sluiten.

H. De MIKOJEL opleidingen bestaan niet meer maar zijn opgegaan in faculteiten van de nieuwe hogescholen.

representativiteit consistentie koppelbaarheid actualiteit toegankelijkheid herhaling

$+\quad+\quad+1-\quad+\quad+(?)$

De resultaten van dit onderzoek zijn niet geschikt voor inpassing in het 
informatiesysteem onderwijs-arbeidsmarkt. Voor geïnteresseerden in 'aansluitingsonderzoek' is het echter aan te bevelen vanwege de gehan teerde systematiek.

\section{Economisch onderwijs}

8. Horeca-opgeleiden op de arbeidsmarkt, SVH-Onderwijscentrum van de bedrijfstak HORECA, Den Haag, 1985.

A. Het onderzoek is opgezet door het SVH Onderwijscentrum van de bedrijfstak horeca door A. van Delft. Dit is een éénmalig onderzoek.

B. Onderzoekspopulatie: oud-leerlingen van de lichtingen 1981, 1982 en 1983 met een voltooide HHS-, MHS-, LBO-opleiding (diff. kok/serveren) of uit het leerlingenstelsel. De Hogere Hotelschool valt onder SOI code 58340 (horeca). Het is niet bekend hoe er met de onderzoeks-populatie contact werd gelegd.

C. Doelstelling: "In hoeverre sluiten de kwaliteiten van oud-leerlingen van horeca-opleidingen en de eisen van de werkgevers in de horeca op elkaar aan."

D. Onderzoekmethode: een schriftelijke enquête onder de oud-leerlingen en interviews onder werkgevers. Het is onbekend hoe de gegevens verwerkt zijn.

E. Belangrijkste onderzoeksvragen: Welke kwalificaties zijn van belang, wat zijn de knelpunten op de arbeidsmarkt. De onderzoeksvragen hadden geen betrekking op het beroep of de sector waarin de oud-leerlingen werkzaam waren.

F. Respons: $401 / 715 * 100 \%=56 \%$ (voor de HHS is dit 59\%). Representativiteit: Het onderzoek beperkte zich tot de Randstad en daarnaast werden hoofdzakelijk die horeca-opgeleiden geënquêteerd die in de horeca werkzaam zijn. Het onderzoek is niet landelijk representatief.

G. Gebruikte indelingen: n.v.t.

H. In de rapportage lag sterk de nadruk op de presentatie van de belang- 
rijkste resultaten. Over de onderzoeksmethode valt derhalve weinig te zeggen. Dit onderzoek geeft wél aan dat ook branche-organisaties belang stellen in 'aansluitingsonderzoek'.

representativiteit consistentie koppelbaarheid actualiteit toegankelijkheid herhaling

Dit onderzoek is niet bruikbaar voor het informatiesysteem onderwijsarbeidsmarkt.

\section{Kunstonderwijs}

9. De samenhang onderwijs-beroepspraktijk in de sector van de beeldende kunsten, SCO, Amsterdam, 1987.

A. Het onderzoek is in 1985 verricht door het SCO in Amsterdam 0.1.v. Haanstra, Koppen en Oostwoud Wijdenes in opdracht van de ministeries van 0 \& W en WVC. Het onderzoek werd vooraf gegaan door een vooronderzoek. Het is echter geen periodiek onderzoek.

B. Onderzoekspopulatie: 150 afgestudeerden van 5 kunstacademies en een steekproef van 150 onder werkenden en werklozen in de toegepaste beeldende kunst en educatieve beroepen.

C. Doelstelling: 1) Hoe verloopt de absorptie van personen met een kunstvakopleiding door het arbeidssysteem; 2) wat is de mobiliteit van personen met een kunstvakopleiding; 3) in hoeverre treden processen van verdringing en verschuiving op in de kunstsector; 4) op welke wijze worden kwalificaties aangeboden en gevraagd.

D. Onderzoekmethode: een schriftelijke enquête onder beide doelgroepen. Onduidelijk is hoe de verwerking heeft plaats gevonden. Voor de analyse werd tevens gebruik gemaakt van CBS-data.

E. Onderzoeksvragen: opleiding; arbeidsduur; beroep (niet geclassificeerd); inkomstenbronnen; werkplaats; aansluiting opleiding werk.

F. Respons en representativiteit: niet bekend. 
G. Indelingen: 20 beroepen in 3 groepen (ook open vragen); Opleiding naar academie en niveau; 23 Bedrijfsgroepen in 5 sectoren ( $\mathrm{nml}$. publiciteit, architectuur \& ontwerp, ind. handel \& nijv., (semi-)overheid en overig). Deze indelingen sluiten niet aan op de CBS-indelingen.

H. Dit onderzoek is geen kwantitatief onderzoek maar een kwalitatief onderzoek waarbij gebruik werd gemaakt van een steekproef.

representativiteit consistentie koppelbaarheid actualiteit toegankelijkheid herhaling ?

+ I?

De resultaten zijn niet bruikbaar voor het informatiesysteem onderwijsarbeidsmarkt.

\subsection{De criteria nogmaals bekeken}

Het eerste criterium betreft de representativiteit. Bij zes van de negen onderzoeken werd een respons bereikt van 60 à $70 \%$. Dit percentage was ofwe 1 aanzienlijk lager bij de resterende drie of er werd geen melding gemaakt van de behaalde respons. Bij twee onderzoeken is gekeken naar de herkomst en spreiding van de respons over de onderzoekspopulatie. Bij geen enkel onderzoek is een aanvullend onderzoek onder de non-responsgroep verricht. Dit betekent dat de twijfels over de representativiteit niet weggenomen kunnen worden omdat het bij eerste bestemmingsonderzoek aannemelijk is dat zich een vertekening voordoet in de respons tussen werkenden en niet-werkenden.

Het tweede criterium betreft de consistentie. Een groot aantal onderzoeken lijkt een aanvaardbare interne consistentie te hebben (weinig 'witte plekken', geen dubbeltellingen). De externe consistentie is echter gering. Onder meer vanwege het gebruik van eigen definities en classificaties. Deze laatste zijn medebepalend voor het derde criterium: de koppelbaarheid met andere bestanden.

Op het punt van deze koppelbaarheid scoren de verschillende onderzoeken over het algemeen vrij slecht: géén van de onderzoeken is direkt koppelbaar met de standaard CBS-indelingen. Dit komt doordat gebruik wordt gemaakt van eigen, meer globale, indelingen die alleen betrekking hebben op de betref- 
fende opleiding en het daarop aansluitende beroepenspectrum en de bijbehorende bedrijfssectoren. Wel is het misschien mogelijk om een aantal van de gebruikte indelingen zodanig aan te passen dat ze wel aansluitbaar zijn. Verder is er bij de twee onderzoeken van wetenschappelijke instituten, het Mikojel-onderzoek van het RION en het onderzoek van het SCO onder afgestudeerden uit het kunstonderwijs, gebruik gemaakt van open vragen voor het achterhalen van werkgever en het beroep. In die gevallen is er in principe wel een koppeling mogelijk tussen de primaire onderzoeksgegevens met de standaardclassificaties. Het aansluitbaar maken op de CBS-indelingen door middel van hercoderen lijkt eveneens mogelijk te zijn voor het NIBI-, NIRIA-, SHAO- en MPAI onderzoek, mits over de primaire data beschikt kan worden.

Over het vierde criterium, actualiteit, behoeft niet veel gezegd te worden: alleen onderzoeken die in de afgelopen 5 jaar zijn verricht zijn in deze inventarisatie betrokken. De enige uitzondering hierop is het MPAI-onderzoek voor de agrarische sector uit 1982. Hoewel dit een verouderd onderzoek is kunnen de resultaten in samenhang met het SHAO-onderzoek nog relevante inzichten leveren. Tevens zijn er een aantal onderzoeken die regelmatig uitgevoerd worden. Het betreft de studies van het NIRIA en de vereniging HBO-J. Ook zijn er plannen voor herhaling van het onderzoek van de SHAO.

De meeste onderzoeksresultaten lijken toegankelijk te zijn doordat de gegevens op een computer zijn opgeslagen. Negatieve uitzonderingen als gevolg van handmatige verwerking van de enquête zijn de studie over de HBO-J afgestudeerden en de studie van de Landelijke hoofddocentenberaden. Van enkele onderzoeken - van het SCO (Kunst) en het SVH (Horeca) - is niet bekend op welke wijze de onderzoeksdata zijn opgeslagen. Het is voor geen van de negen geinventariseerde studies bekend of er bijvoorbeeld juridische- of organisatorische factoren zijn, die het gebruik van het datamateriaal in de weg zouden staan.

\subsection{Conclusies}

Van de geïnventariseerde onderzoeken zijn er vier verricht door een (semi-) wetenschappelijk instituut en vijf door een samenwerkingsverband, beroepsvereniging of brancheorganisatie. Het betreft hoofdzakelijk eenmalige onderzoeken. Alleen in het 'harde HBO' (agrarisch, economisch en technisch) wordt 
regelmatig onderzoek verricht onder afgestudeerden. De doelstellingen van de negen onderzoeken variëren rondom het thema 'aansluiting van onderwijs op arbeidsmarkt'. Als onderzoekmethode wordt vooral gebruik gemaakt van een schriftelijke vragenlijst voor de afgestudeerden. Bij het 'harde HBO' wordt voor de verwerking gebruik gemaakt van optische apparatuur. De onderzoeksvragen die het meest frequent voorkomen hebben betrekking op opleidingsgegevens, de huidige situatie op de arbeidsmarkt, kenmerken van functie of beroep, kenmerken van de arbeidsorganisatie, aspecten van werving en selectie, en scholingsaspecten.

De respons varieert bij zes van de negen onderzoeken van 60 tot $70 \%$ Een analyse van de non-respons is bij geen van de onderzoeken verricht zodat over de representativiteit geen uitsluitsel gegeven kan worden. Bij geen enkel onderzoek wordt gebruik gemaakt van een open vraagstelling met een codering met de standaardclassificaties voor opleiding, bedrijfstak en beroep. In een enkel geval wordt wel gewerkt met een open vraag voor één variabele. Meestal echter, is er sprake van gesloten vragen met een uiteenlopende hoeveelheid antwoordmogelijkheden. Dit kan liggen tussen twee en 76 . Alleen het onderzoek van het NIRIA wordt met een vaste regelmaat verricht.

De resultaten van het NIRIA-onderzoek lijken toegankelijk, consistent, actueel en misschien koppelbaar te zijn. Nadeel is het ontbreken van een vraag naar het uitgeoefende beroep en een daarop aansluitende beroepenclassificatie. In de gehanteerde vragenlijst wordt veel nadruk gelegd op het inkomen en overige arbeidsvoorwaarden. De NIRIA-enquête ging in december 1986 naar 4855 afgestudeerden van de hogescholen voor agrarisch-, laboratorium-, nautisch-, technisch-, economisch- en administratief onderwijs. Het onderzoek wordt jaarlijks gehouden. Afgezien van het bovengenoemde ontbreken van een vraag naar het uitgeoefende beroep zou deze NIRIA-enquête een belangrijke voorbeeldfunctie voor een breed opgezet onderzoek onder HBO-afgestudeerden kunnen hebben.

Een tweede onderzoek dat eventueel mogelijkheden biedt voor inpassing in het informatiesysteem onderwijsarbeidsmarkt is de SHAO-studie De HAO-ingenieur in functie. Dit onderzoek omvat de gehele agrarische sector. Een probleem dat zich hierbij voor zou kunnen doen is de koppeling van de gehanteerde beroepenindeling met de beroepenclassificatie van het CBS. Op de tweede plaats moet nog afgewacht worden of dit onderzoek herhaald wordt. 


\section{CONCLUSIES EN AANBEVELINGEN}

Geconcludeerd kan worden dat er twee organisaties zijn die regelmatig omvangrijk onderzoek verrichten naar de arbeidsmarktpositie van de afgestudeerden van het HBO. Het betreft de Stichting Hoger Agrarisch Onderwijs (SHAO) die onderzoek verricht onder afgestudeerden uit het agrarisch onderwijs, en de ingenieursvereniging NIRIA die samen met de economenvereniging NAHES onderzoek doet onder afgestudeerden van economische en technische HBO-opleidingen. Hoewel de enquêtes die door deze organisaties worden gehouden wat betreft vraagstelling, definiëring van grootheden en gebruikte classificaties nog niet geheel voldoen aan de in dit rapport gestelde criteria lijkt nader overleg met genoemde organisaties over eventuele aanpassingen van de opzet van de onderzoeken zeer aan te bevelen.

Daarnaast worden er op incidentele basis steeds meer adressenbestanden bijgehouden en loopbaanonderzoeken verricht. Deze voldoen echter doorgaans niet aan de in dit rapport gestelde criteria. Naast de reeds genoemde problemen van niet vergelijkbare vraagstellingen, definities en classificaties, gaat het doorgaans om éénmalig of althans niet regelmatig verricht onderzoek, om onderzoek met een beperkte onderzoekspopulatie of met een geringe respons, of om onderzoek met een gebrekkige of beperkte vraagstelling. Een veel voorkomend bezwaar van deze onderzoeken is dat ze veelal niet beschikbaar zijn in de vorm van een toegankelijke dataset. Vaak zijn er allerlei technische, organisatorische en juridische belemmeringen die het gebruik voor secundaire analyses in de weg staan.

De economische sector valt in positieve zin op omdat hier de meeste hogescholen wel op actieve wijze hun afgestudeerden volgen. Dit komt tot uitdrukking in de vele verenigingen van afgestudeerden, de vele databestanden binnen de scholen en de arbeidsmarktonderzoeken die door deze scholen zijn verricht. Helaas zijn de secundaire gebruiksmogelijkheden hiervan beperkt wegens het gebruik van eigen classificaties.

Van de bovengenoemde loopbaanonderzoeken die worden uitgevoerd door de Stichting Hoger Agrarisch Onderwijs (SHAO) en de ingenieursvereniging NIRIA samen met de economenvereniging NAHES, is de secundaire bruikbaarheid beperkt als gevolg van de geringe koppelingsmogelijkheden aan andere bestanden. De geconstrueerde classificaties van beroep en bedrijfstak zijn dusdanig beroeps- en opleidinggebonden dat hercodering, van met name degenen 
die in de restcategorieën terechtkomen, naar de standaardclassificaties niet mogelijk is. Wellicht dat onbekendheid met de CBS-classificaties en ILOdefinities hierbij een rol speelt.

Een mogelijke oplossing voor de genoemde bezwaren is het gebruik van een standaard-vragenlijst voor alle afgestudeerden. In bijvoorbeeld GrootBrittannië, Ontario/ Canada en Zwitserland is men al zeer ver gevorderd met het ontwikkelen en verwerken van dergelijke standaardvragenijjsten voor afgestudeerden. De resultaten van deze 'first-destination surveys' worden verwerkt tot publikaties voor studenten, werkgevers, onderwijs-, onderzoeksen overheidsinstellingen.

In Nederland is met de Registratie Uitstroom en Bestemming van Schoolverlaters (het RUBS-project) voor het voortgezet onderwijs een vergelijkbare ontwikkeling op gang gekomen. In de pilotfase van RUBS zijn in 1989 circa 40.000 schoolverlaters uit het schooljaar 1987/1988 benaderd. Voor de voortzetting van RUBS gaan de gedachten vooralsnog uit naar een regionaal representatieve enquête onder schoolverlaters uit het voortgezet onderwijs10. De daarmee voortgebrachte data zullen gerelateerd moeten kunnen worden aan CBS-gegevens en gegevens van het Ministerie van Onderwijs en Wetenschappen. Daarom wordt voor de codering van de antwoorden gebruik gemaakt van CBS-classificaties.

Ook binnen het Wetenschappelijk Onderwijs is in de afgelopen jaren in toenemende mate onderzoek verricht naar de eerste arbeidsmarktbestemming en de loopbaan van afgestudeerden. Overigens vaak met dezelfde gebreken als de onderzoeken onder afgestudeerden van het Hoger Beroeps Onderwijs. Recentelijk is in het rapport van het ROA Ontwerp van een arbeidsmarktscanner voor academicil1 een model ontwikkeld voor het monitoren door universiteiten en faculteiten van de arbeidsmarktpositie van hun afgestudeerden. Voor dit 'aanbodzijde' onderzoek is een tweetal vragenlijsten ontwikkeld. De 'basisvragenkaart' is bestemd voor degenen die circa een jaar geleden zijn afgestudeerd. Vervolgens wordt voor het actualiseren van de verkregen gegevens jaarlijks een 'jaarkaart' naar de alumni verzonden. Additioneel aan

10. Voor meer informatie over het RUBS-project wordt verwezen naar het eindrapport van het pilotproject 1989, dat in het voorjaar van 1990 door het ROA zal worden uitgebracht.

11. Ontwerp van een arbeidsmarktscanner voor academici, J.W. van Dam, J.A.M. Heijke en G.Ramaekers, ROA-R-1989/3, Maastricht, 1989. 
deze bevragingen dienen ook bij werkgevers periodiek gegevens te worden verzameld. Deze periodieke bevragingen vereisen een voortdurende actualisering van het adressenbestand van de afgestudeerden.

Het systematisch en periodiek beschikbaar komen van informatie over de positie van afgestudeerden op de arbeidsmarkt en het verloop van hun beroepscarrière kan een belangrijke bijdrage leveren aan:

- het traceren en extrapoleren van de structurele trends op de arbeidsmarkt, om zodoende tijdig te kunnen anticiperen op deze trends;

- het vaststellen van de vereiste opleidingscapaciteit van bestaande en nieuw op te zetten curricula;

- het evalueren van de opzet en de inrichting van de bestaande curricula;

- het mede vaststellen van de opzet en de inrichting van nieuwe curricula;

- het informeren van (aankomende) studenten, afgestudeerden, onderwijsgevenden en werkgevers over de arbeidsmarkt- en beroepsmogelijkheden van de verschillende studie- en afstudeerrichtingen.

Uit bovenstaand overzicht van toepassingsgebieden kunnen mogelijke groepen belanghebbenden en hun informatiebehoefte worden afgeleid. Tot de belanghebbenden behoren niet alleen onderzoekers die deze gegevens nodig hebben om analyses te kunnen verrichten en prognoses te kunnen maken op het niveau van studie/afstudeerrichtingen, mar ook en vooral de gebruikers van de analyseen prognoseresultaten. De resultaten van dergelijke analyses en prognoses kunnen onder meer worden gebruikt bij de studie- en beroepskeuze, de arbeidsbemiddeling, de personeelsplanning, de capaciteitsplanning van het onderwijs, de opzet en inrichting van curricula, alsmede de kwaliteitsbewaking van het onderwijs. In dit verband is vooral het recentelijk verschenen 'Uitvoeringsplan Sectorale Kwaliteitszorg' van de HBO-Raad van belang. De registratie en enquêtering van afgestudeerden wordt daarin expliciet genoemd als een belangrijk onderdeel van kwaliteitsinstrumenten als externe verkenning, interne zelfevaluatie en externe visitatie12.

Voor het Hoger Beroeps Onderwijs met zijn vele afstudeerrichtingen en differentiaties zal een integrale benadering van de afgestudeerden moeten worden nagestreefd. Hierbij zal met nadruk moeten worden gezorgd voor een goede coördinatie en samenwerking bij de uitvoering. Bovendien is het wenselijk

12. Uitvoeringsplan Sectorale Kwaliteitszorg, in: Hogeschoolbericht, nr. 74, 17 november 1989, pagina 7 en 10. 
dat er in elk geval tijdens de ontwikkelingsfase een wetenschappelijke begeleiding en advisering plaatsvindt.

Binnen enkele HBO-sectoren is al sprake van samenwerking bij het onderzoek onder afgestudeerden of is een tendens in die richting zichtbaar. Vooral nú echter, moet er voor gewaakt worden dat er niet enkele grote clusters van onderzoekprojecten gaan ontstaan met onderling niet-vergelijkbare onderzoeksmethoden en -technieken. De HBO-Raad zou hierbij een coördinerende rol kunnen spelen. Daarbij zou kunnen worden gedacht aan:

- het meer stelselmatig onder de aandacht van de leden en hun relaties brengen van het nut en de mogelijkheden van actuele en nauwkeurige informatie over de uitstroom en arbeidsmarktbestemming van afgestudeerden;

- het peilen van de behoefte bij hogescholen en faculteiten aan coördinatie of begeleiding bij het opzetten van een monitoringsysteem voor afgestudeerden;

- het bevorderen van het op grotere schaal verzamelen en bijhouden van adressen van afgestudeerden en eventueel hun werkgevers. Daartoe zou aan iedere hogeschool of combinatie van hogescholen een speciale voorziening in de vorm van een bureau of stichting gecreeërd kunnen worden;

- het (laten) ontwikkelen van standaardvragenlijst(en) en de bijbehorende onderzoeksprotocollen (vergelijk de RUBS-vragenlijst);

- het bevorderen van (bestaande initiatieven tot) samenwerking bij het derzoek tussen faculteiten en sectoren. 


\section{LITERATUUR}

Dam, J.W. van, A. de Grip en J.A.M. Heijke, Op zoek naar informatiebronnen over de arbeidsmarktpositie van academici, ROA-W-1988/3, Maastricht.

Dam, J.W. van, J.A.M. Heijke en G.W.M. Ramaekers, Ontwerp van een arbeidsmarktscanner voor academici, ROA-R-1989/3, Maastricht.

Grip, A. de, J.A.M. Heijke, R.J.P. Dekker en L.F.M. Groot, De arbeidsmarktpositie naar beroep in 1992 en de positie van academici daarbinnen, ROA-W--1987/1, Maastricht.

Grip, A. de, en J.A.M. Heijke, Het flexibiliteitspotentieel van universitaire studierichtingen, in: Tijdschrift voor Arbeidsvraagstukken, jaargang 5, $1989 \mathrm{nr} .4$, blz. 69-81.

HBO-Raad, Afdeling Voorlichting, HBO-Almanak 1988, Den Haag.

HBO-Raad Uitvoeringsplan Sectorale Kwaliteitszorg, Hogeschoolbericht, $\mathrm{nr} .74,1989$.

Heijke, J.A.M., Naar een informatiesysteem onderwijs-arbeidsmarkt, onderzoekprogramma 1989/1990, ROA-R-1989/1, Maastricht.

NIPO, Bekendheid en herkenbaarheid, onderzoek naar het imago van hogescholen, onderzoek in opdracht van de HBO-Raad, HBO-Raad, 1990.

Stichting Hoger Agrarisch Onderwijs, De HAO-ingenieur in functie, Wageningen, 1988. 
Naam Hogeschool:

adres:

1) Is er binnen uw instelling iemand die zich bezighoudt met de positie van de afgestudeerden op de arbeidsmarkt en die tevens als contactpersoon voor het ROA zou kunnen optreden?

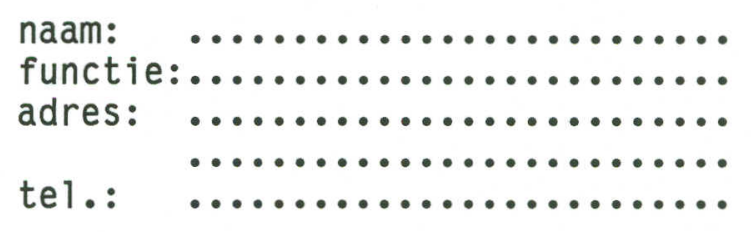

2a) Houdt uw instelling op een min of meer systematische wijze gegevens bij over afgestudeerden ?

0 - NEE, ga verder met vraag 3

0 - JA, gaat het dan om:

$$
\begin{aligned}
& 0 \text { - privé-adres: } \\
& 0 \text { - functie/ beroep: } \\
& 0 \text { - werkgever: } \\
& 0 \text { - andere gegevens: } 1 \ldots \ldots \ldots \ldots \ldots \ldots
\end{aligned}
$$$$
\text { 2..................... }
$$

b) Zijn deze gegevensbestanden in een computer opgeslagen?

0 - JA

0 - NEE

c) Hebben deze gegevens betrekking op de gehele instelling?

$0-\mathrm{JA}$

0 - NEE, om welke studierichting, sector of school gaat het dan?

3) Maakt uw instelling bij de voorlichting aan aankomende studenten melding van de arbeidsmarktperspectieven van de opleiding?

$0-\mathrm{JA}$

0 - NEE 
4a) Heeft uw instelling een vereniging van afgestudeerden?

0 - NEE, ga verder met vraag 5

0 - JA:

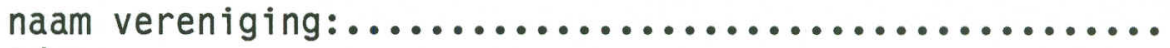

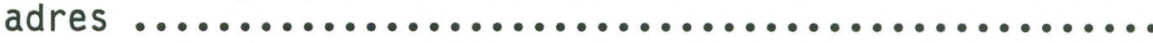

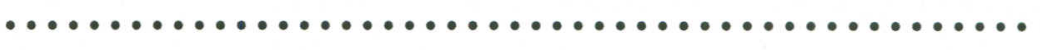

b) Heeft deze vereniging een adressenbestand waarin werkgever en/of functie/beroep van de afgestudeerden zijn opgenomen?

0 - JA

0 - NEE

0 - ONBEKEND

c) Hebben deze gegevens betrekking op de gehele instelling?

0 - JA

0 - NEE, om welke studierichting, sector of school gaat het dan?

5) Is er in de afgelopen 4 jaar onderzoek verricht naar de arbeidsmarktpositie en het loopbaanverloop van de afgestudeerden van uw instelling?

0 - JA, zou u dan een onderzoeksverslag mee willen sturen met deze vragenlijst?

0 - NEE, verwacht u dat er in de komende jaren een onderzoek zal plaatsvinden?

$0-\mathrm{JA}$

0 - NEE

EINDE

De vragenlijst(en) opsturen naar:

Researchcentrum voor Onderwijs en Arbeidsmarkt

t.a.v. M.A. Mortier

Rijksuniversiteit Limburg

Postbus 616

6200 MD MAASTRICHT

Tel: $043-888$ 122/120 
BIJLAGE II: Onderzoeken naar de arbeidsmarktpositie en het loopbaanverloop van de afgestudeerden van HBO-hogescholen

Beknopt overzicht van de inhoud van 18 arbeidsmarktonderzoeken die zijn verricht door faculteiten of vakgroepen van HBO-instellingen en vermelding van 12 onderzoeken die wel op de vragenlijst vermeld werden maar waarvan geen rapport is meegezonden.

Verklaring van de tekst:

naam school

"titel onderzoek"

-samenvatting onderzoek-

criteria m.b.t. eisen zoals werd vermeld in hoofdstuk 2:

- representativiteit

- consistentie

- koppelbaarheid

- actualiteit

- toegankelijkheid

- herhaling

\section{SEKTOR TECHNIEK}

\section{Hogeschool Midden-Nederland}

Stichting Opleiding Leraren, Verslag SOL-enquête '79-'85, Utrecht, 1986.

Verslag van de tweede schriftelijk enquête onder 1430 oud-SOL studenten die afgestudeerd zijn tussen 1979 en 1985, waarvan 72\% respondeerde. 45 open en gesloten onderzoeksvragen m.b.t. arbeidsmarkt waarvan de resultaten m.b.v. SPSS zijn verwerkt.

representativiteit consistentie koppelbaarheid actualiteit toegankelijkheid herhaling ?
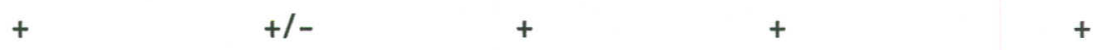

\section{Katholieke Pedagogische School 'De Kempel' Helmond}

Gemeente Helmond, Afdeling Onderzoek, Statistiek en Beleidsontwikkeling, De behoefte aan in Helmond opgeleide leerkrachten bij het basisonderwijs 19851995, Helmond, 1985. 
Het onderzoek is een toekomstverkenning op basis van gegevens van het CBS en van de betreffende opleiding en gemeente.

\begin{tabular}{c|ccccc} 
representativiteit & consistentie koppelbaarheid actualiteit toegankelijkheid herhaling \\
\hline$?$ & & $?$ & - & + & -
\end{tabular}

3. Hogeschool Rotterdam, faculteit educatieve opleidingen (ZWN)

Een baan na het ZWN?, enquête onder de afgestudeerden 1986 en 1987 van de lerarenopleiding ZWN, zesde onderzoek studentendekanaat ZWN, Delft 1988.

Schriftelijke enquête onder ongeveer 600 personen omtrent opleiding en arbeidsmarktpositie. Respons van 47\% (291 reacties) Veel open vragen, geen indelingen. Wordt jaarlijks herhaald.

representativiteit consistentie koppelbaarheid actualiteit toegankelijkheid herhaling

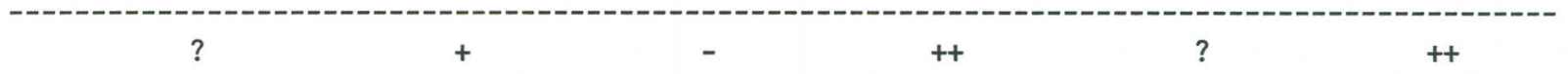

4. Hogeschool Interstudie Arnhem, sector educatief.

Beknopt verslag enquête afgestudeerden 1984, P.G. Kleinbergen, Nijmegen, 1985.

Verslag van een schriftelijke enquête onder 955 afgestudeerden NLO uit de periode 8-'81 t/m 7-'84. Respons van 70\% (664). De onderzoeksvraagstelling is of de NLO opgeleiden binnen of buiten de onderwijssector werkzaam zijn. Werkplek is verder niet gedifferentieerd.

representativiteit consistentie koppelbaarheid actualiteit toegankelijkheid herhaling

Onderzoek dat vermeld is in de vragenlijst maar dat niet is toegezonden:

5. Hogeschool Katholieke Leergangen Sittard.

6. Hogeschool Enschede, sector lerarenopleiding basisonderwijs. 


\section{SEKTOR AGRARISCH ONDERWIJS}

7. Prof. H.C. van Hall Instituut, richting milieukunde

Cohortanalyse, Afgestudeerden milieukunde juni 1987, M.W. van der Sluis, Groningen, dec. 1988.

Verslag van een schriftelijke enquête onder de eerste 40 afgestudeerden in de richting milieukunde met het doel te onderzoeken in welke (milieu-)sectoren de afgestudeerden terecht zijn gekomen en welke studieonderdelen het meest of het minst zinvol bleken.

representativiteit consistentie koppelbaarheid actualiteit toegankelijkheid herhaling ?

\section{SEKTOR TECHNIEK}

8. Noordelijke Hogeschool Leeuwarden, afdeling HTS

titel onbekend,

Bijlage 4 van een verder onbekend gebleven rapport is ons toegezonden. Het bevat de uitstroomgegevens van afgestudeerden van verschillende afstudeerrichtingen voor de jaren $1978 \mathrm{t} / \mathrm{m}$ 1987. Totaal gaat het om 264 afgestudeerden, waarvan er 239 werden opgespoord. Binnen de studierichting zijn de gegevens gedifferentieerd naar werkplaats of andere maatschappelijke plaats. Deze gegevens zijn niet gestandaardiseerd.

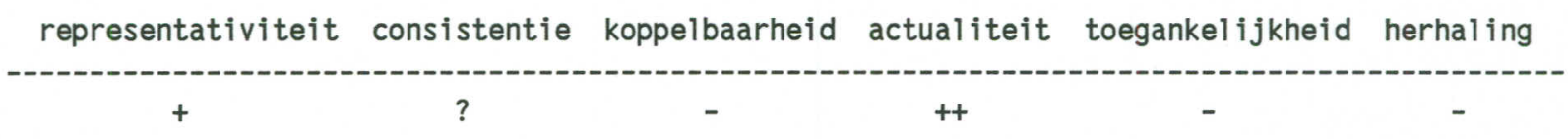

9. Hogeschool Interstudie Arnhem, sector techniek.

Enquête onder de afgestudeerden MLO en HLO chemische richting die in juni 1987 eindexamen hebben gedaan, Arnhem, 1988.

Beknopt verslag van een schriftelijke enquête onder 20 HLO afgestudeerden.

representativiteit consistentie koppelbaarheid actualiteit toegankelijkheid herhaling 
Onderzoek dat vermeld is in de vragenlijst maar dat niet is toegezonden:

10. Hogeschool West-Brabant, sector HLO.

\section{SECTOR GEZONDHEIDSZORG}

\section{Opleiding Oefentherapie Cesar, Den Dolder}

Rapport eerste fase onderzoek 1986 naar de resultaten van de oefentherapie cesar in de eerstelijnsgezondheidszorg, H.C. Hasper, Den Dolder 1986.

Compilatie van vier onderzoeken en gegevensbestanden met ondermeer een arbeidsmarktgedeelte met daarin kengetallen over inkomen, arbeidsduur en werkplek van de ongeveer 800 beroepsbeoefenaren, voor vier perioden.

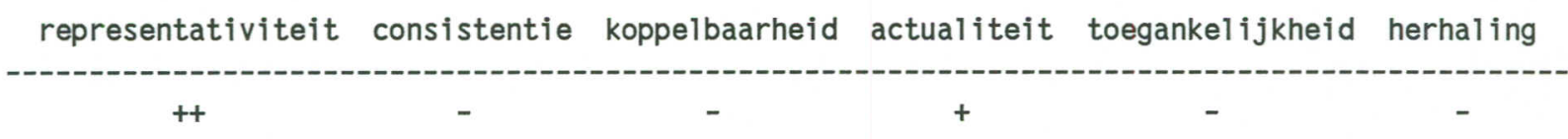

12. Haagse Hogeschool, sector gezondheidszorg

Een jaar na het beëindigen van de opleiding tot fysiotherapeut, in: Fysiovisie, 1987, J.A. van den Berg e.a.

Uitslag van de vierde telefonische enquête onder 68 aan de Haagse Hogeschool afgestudeerde fysiotherapeuten. Arbeidsmarktkentallen met betrekking tot werkloosheid/soort werk, arbeidsduur, werksector en wijze van het verwerven van een werkkring.

representativiteit consistentie koppelbaarheid actualiteit toegankelijkheid herhaling

$+\quad+\quad-\quad+\quad+$

13. Prot. Chr. Hogeschool De Vijuerberg, Ede

Enquête (V)HBOV afgestudeerden 1987, aanbevelingen en resultaten, A.J. Leeuwis, Ede, 1988.

Verslag van een schriftelijke enquête onder 93 afgestudeerden HBOV. Doel van de enquête was het achterhalen van de mening van oud-studenten over het genoten onderwijs, de onderwijsorganisatie alsmede naar de huidige werkkring. Vragen over de werkkring hadden betrekking op de aard van het dienstverband, de werkkring in de gezondheidszorg en het gebruik van 
computers. Geen vragen omtrent functie inhoud. Mogelijk wordt deze enquête in de toekomst herhaald.

\begin{tabular}{ccccc} 
representativiteit consistentie koppelbaarheid actualiteit toegankelijkheid herhaling \\
\hline+ & $+/-$ & - & ++ & -
\end{tabular}

\section{SEKTOR ECONOMIE}

\section{Hanzehogeschool Groningen/ Instituut THW}

THW voorlichters en de arbeidsmarkt, een onderzoek naar de aansluiting van het onderwijs van de THW-voorlichting (Groningen) met de arbeidsmarkt, L. Kamminga e.a., Groningen, 1989.

Onderzoeksrapport met verslag van een schriftelijke enquête onder 68 afgestudeerden van de THW-Voorlichting van de jaren $1983 \mathrm{t} / \mathrm{m}$ 1987. Respons van $60 \%$ (40) van de aanbodkant. Alle mogelijke aspecten van arbeidsmarktsituatie zijn belicht. Tevens analyse van de vraagzijde, onder andere met een vacature onderzoek. Dit lijkt een eenmalig onderzoek.

representativiteit consistentie koppelbaarheid actualiteit toegankelijkheid herhaling

\section{Hanzehogeschool Groningen/ Insituut voor Economisch Onderwijs}

De maatschappelijke positie van recent afgestudeerden van het instituut voor Hoger Economische Studies te Groningen, A.R. Kamps, Groningen, 1987.

Verslag van een schriftelijke enquête onder alle 518 in 1985 en 1986 afgestudeerden aan het HES. Respons van $63 \%$ (326). Doel van de enquête is de ontwikkelingen van de HES-er op de arbeidsmarkt te kunnen volgen en het opbouwen van een adressenbestand en het kunnen geven van voorlichting. Dergelijke enquête is tevens onder de afgestudeerden van 1983 en 1984 gehouden. De gebruikelijke vragen met betrekking tot de huidige maatschappelijke positie.

representativiteit consistentie koppelbaarheid actualiteit toegankelijkheid herhaling 


\section{Hogeschool Enschede, sector Economie}

Enquêteresultaten en samenvatting van enquête gehouden onder de afgestudeerden van de economisch-linguïstische studierichting van de HES Enschede in de periode van okt/dec 1987.

Verslag van een schriftelijke enquête onder alle 256 afgestudeerden ( $t / m$ 1987). Respons van 50\% (128). Bevat vragen omtrent de maatschappelijke plaats en/of de arbeidsmarktpositie. Bij de eigen indelingen werd gebruik gemaakt van 17 bedrijfstakken en 10 beroepsgroepen. Deze zijn wellicht koppelbaar.

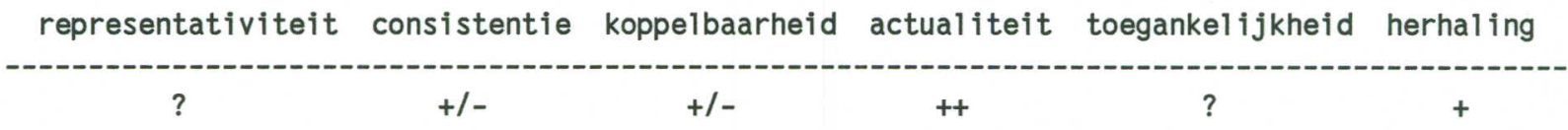

\section{Hogeschool voor Tourisme en Verkeer, sector toerisme en recreatie}

Resultaten afgestudeerden per 25 februari 1986, Breda, 1987.

Verslag van gegevens uit het afgestudeerdenbestand. Deze gegevens hebben betrekking op 1347 afgestudeerden, wat tevens de totale populatie is. (waarschijnlijk alle afgestudeerden t/m 1986) Specificaties naar geslacht, voornaamste werkgever (open ?) en aard van de functie (open ?). Onduidelijk is hoe het bestand is opgebouwd en welke andere gegevens er aanwezig zijn.

representativiteit consistentie koppelbaarheid actualiteit toegankelijkheid herhaling

$++\quad+$

$?$

$+$

\section{Hogeschool Alkmaar, sector Economie}

Enquête huidige maatschappelijke positie, Alkmaar, april 1988.

Verslag van enquête onder alle HEAO Alkmaar afgestudeerden van het studiejaar 86/87. Respons van $72 \%$ op de 148 geslaagden. Open vraag met betrekking op huidig beroep, keuze mogelijkheid uit drie sectoren. Enquête resultaten gaan ondermeer gebruikt worden bij voorlichting.

\begin{tabular}{rrrr} 
representativiteit consistentie koppelbaarheid actualiteit toegankelijkheid herhaling \\
\hline
\end{tabular}


Onderzoek dat wel vermeld is in de vragenlijst maar niet is toegezonden:

19. HEAO Arnhem

20. Hogeschool Zeeland, sector HEAO

21. Hogeschool voor Economische Studies Rotterdam (medewerking aan RUBS-project, i.s.m. COA Rijndelta)

22. Rijkshogeschool Opleiding tot Vertaler, Maastricht

23. Hotelschool Den Haag

24. Hogeschool West-Brabant, sector HEAO (moest nog gepubliceerd worden)

25. Chr. Hogeschool Windesheim, sector HEAO

26. Meerdere HBO-opleidingen: Hogeschool Midden-Brabant/ Akademie voor documentatie en informatieverzorging, Rijkshogeschool Maastricht studierichting BDI, en bibliotheekacademies uit Amsterdam, Deventer, Den Haag, Groningen en Sittard.

Enquête omtrent de arbeidsmarktpositie van de afgestudeerden van alle bibliotheekacademies gehouden onder de afgestudeerden van $1986 \mathrm{t} / \mathrm{m}$ 1988. De geretourneerde enquêtes zijn nog niet verwerkt.

\section{SECTOR SOCIAAL-AGOGISCH ONDERWIJS}

\section{Christelijke Hogeschool Rijn-Delfland, Oegstgeest}

Enquête afgestudeerden '87/'88, okt. 1988, Oegstgeest.

Kort verslag van een schriftelijke enquête onder 54 afgestudeerden van de studierichting $\mathrm{HBO}-\mathrm{J}$. De respons was $80 \%$ (37). Vragen met betrekking tot aard van het werk en werkveld, reden van werkloosheid en de kanalen waarlangs een baan verkregen is. Zie verder voor HBO-J afgestudeerden het onderzoek van de Vereniging HBO-J uit 1987

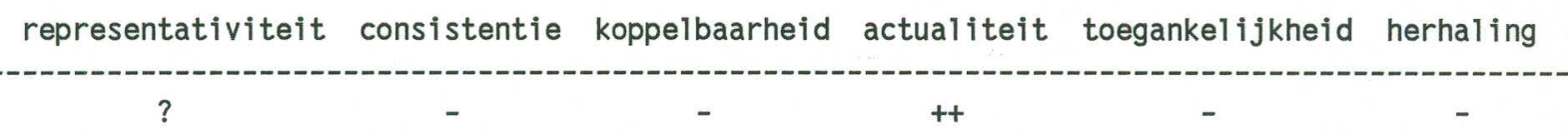

28. Hogeschool West-Brabant, voltijdopleiding personeelsmanagement

Enige conclusies m.b.t. afgestudeerden voltijdopleiding PM 1985 en 1986, R. de Groot, Breda, 1988.

Kort verslag van een enquête onder 70 afgestudeerden. De enquête had 
betrekking op het al dan niet werkzaam zijn van de afgestudeerde in het personeelswerk en op het achterhalen van eventuele vervolgopleidingen.

representativiteit consistentie koppelbaarheid actualiteit toegankelijkheid herhaling ?

\section{SECTOR KUNSTONDERWIJS}

29. Dr. Gerrit Th. Rietveld Academie, Amsterdam

De Gerrit Rietveld Academie 1980-1987: cijfers, feiten en activiteiten, Amsterdam, februari 1988.

Boekwerk geeft in het hoofdstuk "Aansluiting op de beroepspraktijk" een cumulatief overzicht van het al dan niet werkzaam zijn (in de beeldende kunst sector) van afgestudeerden uit de jaren $1980 \mathrm{t} / \mathrm{m}$ 1987. De vermelde gegevens zijn niet bruikbaar.

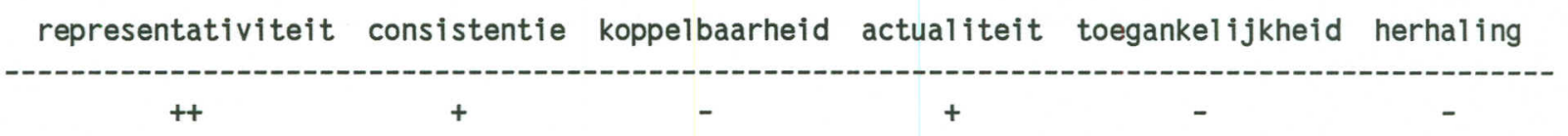

Onderzoek dat is vermeld in de vragenlijst maar dat niet is toegezonden:

30. Academie Industriële Vormgeving Eindhoven 
BIJLAGE III

Tabel III.1 De mate waarin door faculteiten gegevens over afgestudeerden worden bijgehouden, per HBO-sector

HBO-sector

(1)

(2)

(3)

(4)

(5)

1 - pedagogisch

36

13

2

12

36.1

2 - agrarisch

2

1

1

0

1

3 - technisch

26

50.0

6

23.1

4 - gezondheidszorg

23

7

30.4

5 - economisch

30

16

11

53.3

6 - sociaal-agogisch

17

8

47.1

7 - kunst

15

8

53.3

3

5

3

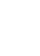

2

4

6

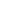

3

11

15

.1

3

3

4

7

Totaal

150

59

23

32

49

39.3

(1) totaal = aantal faculteiten die een enquête geretourneerd hebben.

(2) gegevens = aantal faculteiten die gegevens bijhouden.

(3) PC = aantal faculteiten van (2) die dat bijhouden op een computer.

(4) soort = aantal faculteiten van (2) waarvan het gegevensbestand volledig is (adres/beroep/werkgever).

(5) sector = aantal faculteiten van (2) waarvan het gegevensbestand alle afgestudeerden betreft van de desbetreffende faculteit. 


\section{BIJLAGE IV}

Tabel III.2 Voorlichting en onderzoek per HBO-sector: verleden en voornemens

\begin{tabular}{|c|c|c|c|c|}
\hline \multirow[b]{2}{*}{ HBO-sector } & \multirow{2}{*}{$\begin{array}{l}\text { totaal } \\
\text { (1) }\end{array}$} & \multirow{2}{*}{$\begin{array}{l}\text { voorlichting } \\
\text { (2) }\end{array}$} & \multirow{2}{*}{$\begin{array}{l}\text { research } \\
\text { verleden } \\
\text { (3) }\end{array}$} & \multirow{2}{*}{$\begin{array}{c}\text { research } \\
\text { toekomst } \\
\text { (4) }\end{array}$} \\
\hline & & & & \\
\hline \multirow[t]{2}{*}{1 - pedagogisch } & 36 & 34 & 8 & 13 \\
\hline & & 94.4 & 22.2 & 36.1 \\
\hline \multirow[t]{2}{*}{2 - agrarisch } & 2 & 2 & 1 & 0 \\
\hline & & 100.0 & 50.0 & 0.0 \\
\hline \multirow{2}{*}{3 - technisch } & 26 & 26 & 4 & 12 \\
\hline & & 100.0 & 15.4 & 46.2 \\
\hline \multirow[t]{2}{*}{4 - gezondheidszorg } & 23 & 23 & 6 & 7 \\
\hline & & 100.0 & 26.1 & 30.4 \\
\hline \multirow[t]{2}{*}{5 - economisch } & 30 & 29 & 18 & 7 \\
\hline & & 96.7 & 60.0 & 23.3 \\
\hline \multirow[t]{2}{*}{6 - sociaal-agogisch } & 17 & 17 & 6 & 7 \\
\hline & & 100.0 & 35.3 & 41.2 \\
\hline \multirow[t]{2}{*}{7 - kunst } & 15 & 12 & 2 & 7 \\
\hline & & 80.0 & 13.3 & 46.7 \\
\hline \multirow[t]{2}{*}{ Totaal } & 150 & 144 & 45 & 53 \\
\hline & & 96.0 & 30.0 & 35.3 \\
\hline
\end{tabular}

(1) totaal = aantal faculteiten die gereageerd hebben.

(2) voorlichting = aantal faculteiten die bij hun voorlichting naar aankomende studenten melding maken van de arbeidsmarktperspectieven.

(3) research verleden = aantal faculteiten die arbeidsmarktonderzoek hebben verricht onder hun afgestudeerden.

(4) research toekomst $=$ aantal faculteiten die in de toekomst van plan zijn arbeidsmarktonderzoek te verrichten. 


\section{Vragenlijst voor schoolverlaters \\ MBO, KMBO, HAVO/VWO en HBO 1987/88}

Enkele algemene gegevens

1. Wanneer ben je geboren?

2. Geslacht:

3. Welke taal spreek je thuis meestal met je ouders/verzorgers? jaar: 19

maand:

man

vrouw

Nederlands (ook streektaal of dialect)

Surinaams of Antilliaans

Turks of Marokkaans

Westeuropese taal (b.v. Frans, Duits)

Zuideuropese taal (b.v. Spaans, Grieks)

andere taal:

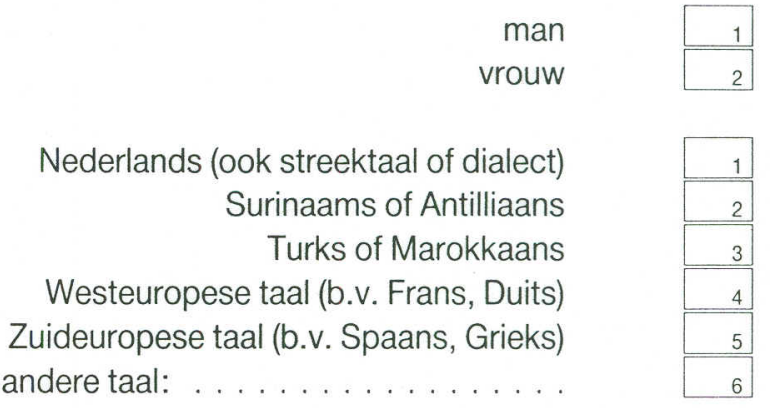

4. Woonplaats:

De opleiding in het schooljaar 1987/88 (vorig jaar)

5 a. Heb je van deze opleiding vorig jaar het diploma behaald?

nee

ja

alleen deelcertificaten

alleen theorie-examen

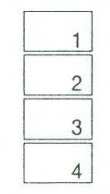

b. In welke klas/studiejaar ben je vorig jaar van school gegaan?

klas:

c. Wat is het laatste onderwijsdiploma dat je gehaald

hebt vóór de opleiding van vorig jaar?

(bijvoorbeeld LTS-bouw, MAVO, HAVO, MDGO-AW)

\section{Huidige bezigheden}

6. Volg je op dit moment een opleiding in het leerlingwezen (streekschool e.d.)

of een in-service opleiding in de verpleging of verzorging?

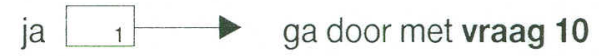

nee

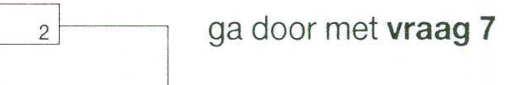

7. Wat is op dit moment je voornaamste bezigheid?

- $\quad$ full-time dagopleiding (meer dan 3 dagen per week)

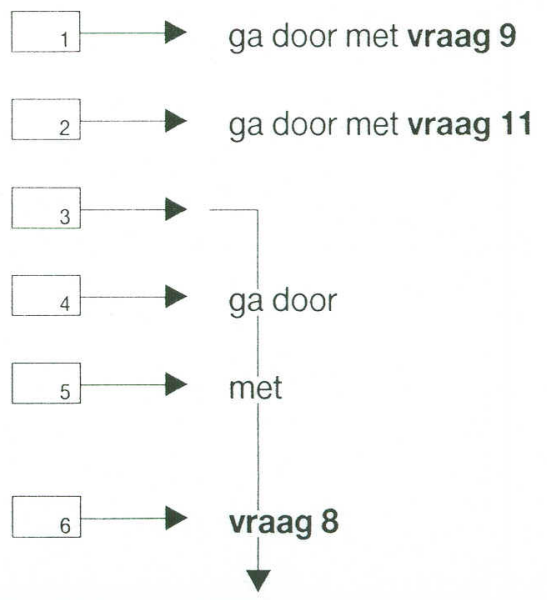


8 a. Heb je een betaalde baan gehad sinds je van school bent?

nee

b. Zo ja, hoeveel maanden heb je in totaal gewerkt?

maanden:

Ga door met vraag 16

\section{De opleiding die je nu volgt}

Voor degenen die een full-time dagopleiding volgen:

9 a. Welke opleiding volg je op dit moment? (bijvoorbeeld: HAVO, KMBO, MTS, HTS, HBO-J)

b. Welke vakrichting, afdeling of specialisatie doe je binnen deze opleiding?

(bijvoorbeeld: Bouwkunde, Bestuurskunde, Jeugdwelzijnswerk)

Ga door met vraag 16

Voor degenen die een opleiding in het leerlingwezen (streekschool e.d.) of een in-service opleiding volgen:

10 a. Wat voor opleiding volg je op dit moment?

(bijvoorbeeld: automonteur, installatietechniek, ziekenverzorgende, A-verpleegkundige)

b. Naam leerlingstelsel:

(ECABO, VAM, SOM (metaal), VEV (electro), OVDB, Kappers, Horeca en dergelijke)

c. Heb je naast deze opleiding een

betaalde baan?

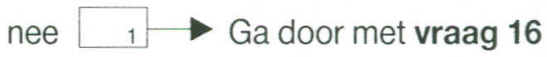

ja $\quad 2 \quad$ Ga door met vraag 11

Je huidige werk en beroep

11 a. Werk je in loondienst?

nee

ja

b. Wat voor aanstelling heb je?

vaste aanstelling tijdelijke aanstelling werk voor uitzendbureau

c. Hoeveel uur per week werk je meestal?

minder dan 20 uur 20 tot 32 uur meer dan 32 uur 
12 a. Hoe ben je aan dit werk gekomen? (één antwoord aankruisen)

via het Arbeidsbureau via familie of kennissen

via een advertentie in de krant via een advertentie in een winkel e.d.

via een uitzendbureau

via vakantiewerk/bijbaantje

door de stage/via de school

zelf aan de werkgever om werk gevraagd

voor mijzelf begonnen

anders:

vor mizelf begonnen

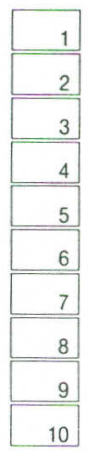

b. Hoe snel heb je werk gevonden

meteen

toen je vorig jaar van school ging?

na 1 - 3 maanden

na 4 - 6 maanden

na meer dan 6 maanden

13 a. Hoe heet het beroep of de functie die je uitoefent?

(bijvoorbeeld: secretaresse, tuinder, groepsleider, bouwkundig tekenaar, verkoopster)

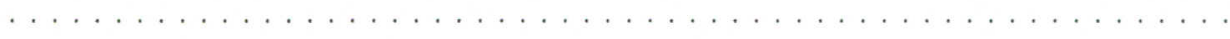

b. Wat zijn je voornaamste werkzaamheden?

(bijvoorbeeld: technisch tekenen, veeverzorging, typen, boekhouden)

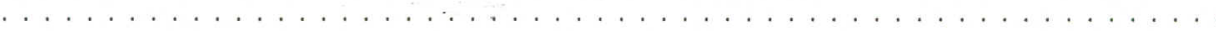

c. Op wat voor afdeling werk je?

(bijvoorbeeld: administratie, montagehal, magazijn, receptie, operatiekamer)

$\ldots \ldots \ldots \ldots \ldots \ldots \ldots \ldots \ldots \ldots \ldots \ldots \ldots \ldots \ldots \ldots \ldots \ldots \ldots \ldots$

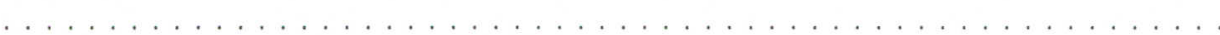

d. Geef je leiding aan ander personeel?

aantal personen: . . . . . . . .

nee
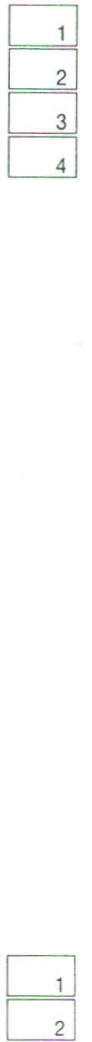
16 a. Heb je de afgelopen 4 weken naar (ander) werk gezocht?

b. Zo ja, hoe heb je de afgelopen 4 weken

via het Arbeidsbureau naar werk gezocht? (LET OP: meer antwoorden mogelijk)

via familie of kennissen

via advertenties in de krant via advertenties in winkels e.d.

via een uitzendbureau via de stage/school zelf aan een werkgever om werk gevraagd anders:

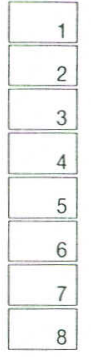

c. Sta je ingeschreven bij het Arbeidsbureau?

nee

17 a. Volg je een (nog een andere) cursus, training of part-time opleiding?

nee

b. Welke?

\section{De opleiding achteraf bezien}

18. Hieronder noemen we een aantal zaken. Geef aan of daar in de opleiding van vorig jaar (1987/88 dus) voldoende aandacht aan is besteed. Ga daarbij uit van wat je nu doet:

$\begin{array}{cccc}\text { te } & \text { vol- } & \text { te } & \text { nietvan } \\ \text { veel } & \text { doende } & \text { weinig } & \text { toepassing }\end{array}$

a. Vakkennis/vaktheorie

b. Vreemde talen (Engels, Duits e.d.)

c. Een brief of een stuk schrijven

d. Met cijfers werken (wiskunde, rekenen)

e. Zelfstandig werken

f. Samenwerken met collega's

g. Met mensen omgaan

h. Praktijkoriëntatie of stage

i. Omgaan met apparatuur en materialen

j. Weten hoe een bedrijf georganiseerd is

k. Leiding geven

I. Organiseren/plannen

$\mathrm{m}$. Beroepskeuze/studiekeuze

n. Leren studeren

o. Kennis van arbeidsvoorwaarden
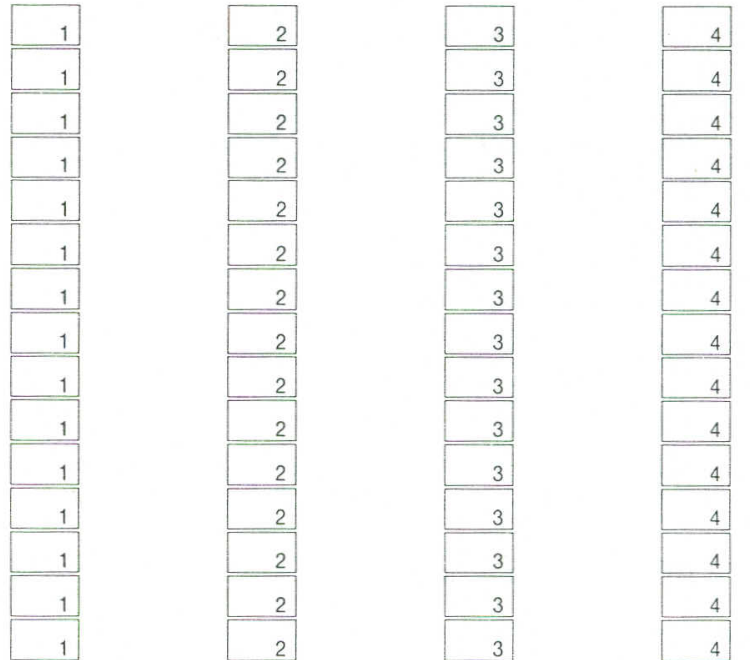
(CAO, ondernemingsraad, wat te doen bij ontslag e.d.)

Ruimte voor opmerkingen

Bedankt voor het invullen

Stuur de vragenlijst zo snel mogelijk op in de antwoordenvelop (een postzegel is niet nodig) 